\title{
Financial Inclusion in Egypt: Challenges and Recommendations
} Heba Mahmoud El-Baz"(1)

\section{Abstract:}

Financial inclusion is receiving an increased attention for its potential beneficial financial and economic impacts. It can enhance financial stability, promote economic growth, reduce income inequality and alleviate poverty. Driven by the Egyptian authorities' trust in the importance of the inclusion of all society segments into the formal financial system, they made several efforts and adopted different measures. Despite these efforts, challenges remain and necessitate further efforts to be undertaken to confront persistent modest levels of financial inclusion. This study aims to demonstrate the currently expanding Egyptian experience of financial inclusion, the governmental efforts to effectively boost it and the challenges that are still encountered.

The study finds that Egypt suffers from high levels of financial exclusion, especially when compared to other countries groups. Analysis of the access, usage and quality of financial services used by individuals or enterprises clarified that many Egyptians are still excluded from the formal financial system in many aspects. Cost, lack of documentation and distance barriers play considerable roles in this financial exclusion. Women, low-income and young adults are over-represented among the unbanked. There is greater preference of cash transactions in receiving wages, sending or receiving domestic remittances and saving/ borrowing informally.

(1) Assistant Professor of Economics and chief of Fiscal and Monetary Policies Department, at The Macroeconomic Policies Center, Institute of National Planning (INP), Egypt. 
Mobile money accounts and digital transactions are recording low levels. Possibility of raising emergency funds is faint. Also, firms' access to finance and usage indicators in Egypt didn't improve significantly over the past years.

To face these challenges, the study recommends actual steps to expand electronic banking and mobile money services, to revolutionize post offices, and to remove physical, bureaucratic, and financial barriers hindering financial inclusion. Interest rates and collateral requirements need to be revised to ameliorate firms' access to finance. A bank's collateral regime, ready to accept a growing share of movable assets, is important. Finally, a financial inclusion strategy with specific targets need to be settled and adopted

Key Words: financial inclusion, Egypt, Africa, financial services, financial stability

\section{Introduction:}

Financial inclusion simply refers to the degree of access of households and firms, especially poorer households and small and medium-sized enterprises (SMEs), to financial services ${ }^{(1)}$. It targets the "unbanked" population to be drawn into the formal financial system. In turn, the "unbanked" will have the opportunity to access financial services as credit, savings, payments, transfers and insurance) $)^{(2)}$.

(1) Naoyuki Yoshino and Peter J. Morgan. "Financial inclusion, financial stability and income inequality: Introduction". The Singapore Economic Review (SER), Vol. 63(1). March 2018, pp.1.

(2) - Alfred Hannig and Stefan Jansen, "Financial inclusion and financial stability: Current policy issues", ADBI Working Paper, No.259, 2010, p.1.

- Peter Morgan, and Victor Pontines, "Financial stability and financial inclusion", ADBI Working Paper Series, No.488, 2014, p.5. 
Financial inclusion is on the rise globally. The 2017 Global Findex database highlighted that $\% 67$ of adults over the world had an account at a financial institution, up from $\% 61$ percent in 2014, and \%51 percent in 2011. Interest in promoting financial inclusion has grown exponentially in recent years. This is due to its potential beneficial financial and economic impacts such as household consumption and activities, business activities, banks' non-performing loans, financial stability, GDP growth, income equality and poverty.

Being concerned with these potential benefits, Egypt took serious and firm steps in order to enhance financial inclusion. So, this study aims to demonstrate the currently expanding experience of financial inclusion in Egypt and the governmental efforts to effectively boost it as well as the challenges that are encountered.

The importance of this study stems from providing a full descriptive analysis of the Egyptian experience and provision of key messages for a successfully accomplished financial inclusion in Egypt.

The adopted methodology consists of a review of previous related literatures and empirical studies concerned about the impacts and benefits of financial inclusion. In addition, an indepth analysis of how financial inclusion indicators developed in this current Egyptian case study will be presented. Using the comparative approach, the Egyptian experience will be demonstrated head to head in comparison with "Low Middle Income Countries" (LMIC) and "Middle East North Africa" (MENA) groups. Finally, following the critical approach, a comprehensive analysis to the Egyptian experiment will be developed. 
The study draws on several sources of data such as the World Bank Global Findex database, the World Bank Global Financial Development database (GFDD), the World Bank Enterprise surveys and the Central Bank of Egypt (CBE) database. This variety of sources will expose many aspects of financial inclusion.

\section{1 - What is financial inclusion?}

On 10 December 2010, the Global Partnership for Financial Inclusion (GPFI) was launched, at the G20 Summit in Seoul, as a main platform for all G20 countries, interested non-G20 countries as well as relevant stakeholders aiming to carry forward the work on financial inclusion. The GPFI is dedicated to advancing financial inclusion globally. This is performed through empowering the quality access to, and usage of, different sustainable formal financial services, thereby expanding the opportunities for excluded households and enterprises ${ }^{(1)}$.

To achieve these goals, the GPFI works in collaboration with different partners such as: the Alliance for Financial Inclusion (AFI), the International Finance Corporation (IFC), the Consultative Group to Assist the Poor (CGAP), the World Bank, the SME Finance Forum, the Better than Cash Alliance, etc...

Despite all these works and efforts, there is no standard or universally accepted definition of financial inclusion. If present, official definitions typically include the availability and use of the financial services as main dimensions of financial inclusion, still there are other aspects as well(2).

(1) Global partnership for financial inclusion (GPFI), "About GPFI", (N.d.), http:INWWW.gpfi.erg/ about-gpti (accessed January 17, 2019).

(2) Bank for International Settlements (BIS), "Measures of financial inclusion - a central bank perspective", IFC report, Irving Fisher Committee on Central Bank Statistics, 2016, p.5. 
The World Bank mentioned that financial inclusion refers to "individuals and businesses have access to useful and affordable financial products and services that meet their needs transactions, payments, savings, credit and insurance- delivered in a responsible and sustainable way"(1). According to the GPFI, financial inclusion means that "all working-age adults (persons at the age of +15 ) have effective and quality access to, and usage of - at a cost affordable to the customers and sustainable for the providers - financial services provided by formal institutions"(2).

Clearly, the World Bank limited its definition to the access to financial services, while the GPFI provides a broader definition as it extends to the usage of them, additionally taking into consideration the quality of these services. The fact that a customer can access services provided by a formal financial service provider does not necessarily signify, according to the GPFI, that he or she is "financially included". Indeed, the conditions of "effective access" must be present. The demonstration of effective access is usage of the financial services ${ }^{(3)}$.

In this context, "access" does not signify any sort of access but necessitates an "effective access" that includes the suitable and responsible delivery of services that meets the needs of underserved and financially excluded customers at a cost that is affordable to the customers and sustainable for the providers. This is associated with accompanying safeguards such as adequate

(1) The World Bank, "Financial Inclusion at a glance", 2018, http// www. Worldbank.org (accessed January 12, 2019)

(2) Global partnership for financial inclusion (GPFI) (2017) "Financial inclusion action plan", 2017, p.6, http/IMWW/gpfi.erg/sites/grfifiles/decuments/2017\%20G20\%20Financial\%20Inclusion\%20Action\%20Plan\%20final.pdf (accessed January 21, 2019).

(3) Ibid, p.6. 
regulations and laws to protect consumers against deceptive practices ${ }^{(1)}$.

Finally, it is important to differentiate between the voluntary excluded who do not wish to or need to use such products and services and those who wish to use them but can't do so for different reasons as insufficient funds, distance obstacles, high costs, lack of documentation, etc...

\section{2- Advantages of financial inclusion:}

Financial inclusion has potential beneficial financial and economic impacts. It helps to achieve multiple macroeconomic goals such as enhancing financial stability, promoting economic growth, reducing income inequality and alleviating poverty.

\section{2-1- Financial inclusion and financial stability:}

Financial inclusion has important positive implications for financial stability. Several studies including Han and Melecky (2013) and Morgan and Pontines (2014) have established a strong relationship between financial inclusion and financial stability.

There are several reasons why increased financial inclusion may support the central bank's task of achieving financial stability. First, financial inclusion improves households and enterprises' access to credit and increases lending especially to smaller enterprises. In turn, this allows the financial institutions to diversify their loan portfolios, minimize the relative weight of any single borrower in the overall portfolio and reduce volatility. As a result, this ends up with lowering the average credit risk of loan portfolios and the systemic risks ${ }^{(2)}$.

(1) Naoyuki Yoshino and Peter J. Morgan, Op.cit., p.2.

(2) - Aaron Mehrotra and James Yetman, "Financial inclusion - issues for central banks", BIS Quarterly Review, March 2015, p.91.

- Naoyuki Yoshino and Peter J. Morgan, Op.cit., p.4. 
Morgan and Pontines (2014) found that increasing the share of credit allocated to SMEs in total bank lending is mainly accompanied with a decrease in non-performing loans as well as a diminution of financial institutions defaults' probability. This will eventually lead to financial stability.

Second, consumers who gain access to the formal financial system augment aggregate savings and diversify the banks' deposit base. That will lead to more stable retail base of deposits and subsequently will improve the resilience of financial institutions. This, in turn, support the overall financial stability of the banking sector and the entire financial system ${ }^{(1)}$.

This resilience is important, especially during crises, when depositors get anxious and withdraw their deposits. These correlated withdrawals could be mitigated if the bank deposits were more diversified and held by more customers. Additionally, large depositors are mostly the first ones to run in crises times while the relatively lower-income depositors tend to keep steady financial behavior and maintain their deposits ${ }^{(2)}$.

Indeed, during the 2008 global financial crisis, deposits were minimally affected in economies where the degree of financial inclusion -measured in bank deposits- was greater. Han and Melecky (2013) assessed the impact of access' degree to bank deposits on the stability of deposit growth during the crisis in 95

(1) - Robert Cull, Tilman Ehrbeck, and Nina Holle, "Financial Inclusion and Development: Recent Impact Evidence", CGAP Focus Note 92, Consultative Group to Assist the Poor, April 2014, p.2\&3.

- Alfred Hannig and Stelan Jansen, Op. cit., p. 21.

(2) - Shri Khan, "Financial inclusion and financial stability: Are they two sides of the same coin?", BIS central bankers' speeches, November 4, 2011, p.4, http:/NWW.bis.org/review/r111229f.pdf (accessed March 2, 2019).

- Rui Han and Martin Melecky, "Financial inclusion for stability: Access to bank deposits and the deposit growth during the global financial crisis", MPRA Papers, No. 48338, March 2013, p.1. 
countries. They concluded that higher access to bank deposits enhanced resilience of the deposit's funding base of the banking sector during financial crises. They also demonstrated that a $\% 10$ rise in the percentage of population who have access to bank deposits can mitigate the decrease in deposit growth (or withdrawal rates) by about $\% 8-3$ points.

Third, financial inclusion helps to attain higher degrees of citizens' contributions in the formal financial system. To mention, the existence of a considerable informal sector can hamper the transmission of monetary policy since a significant division of financially excluded households and small businesses make their financial decisions independent of, and uninfluenced by, the central's bank monetary policy. As the percentage of citizens included in the formal financial sector increases through greater financial inclusion, a higher degree of monetary policy transmission is expected. Subsequently, monetary policy becomes more effective ${ }^{(1)}$.

\section{2-2- Financial inclusion and economic growth:}

Beside its potential effect on financial stability, financial inclusion can additionally promote economic growth. Several empirical studies (including Honohan (2003); Sahay and others (2015) and Neaime (2018)) found that financial inclusion can lead to considerable benefits to the economic growth. Once people access the formal financial system, they are more able to start or expand businesses, invest in education, manage financial risks and overcome financial shocks. In addition, access to accounts, savings, credit and payment alternatives increases savings, and boosts productive investment as well as consumption.

(1) Shri Khan, Op. cit., p.4. 
According to Hannig and Jansen (2010), Dabla-Norris and others (2015), and Zulfiqar and others (2016), financial inclusion enables more efficient intermediation and allocation of resources and funds among savers and investors. it also allows people to contribute in the growth process through increasing their degree of access to economic opportunities and expanding their choices. That, sequentially, turn them to more efficient and productive economic agents.

Collectively, financial inclusion allows people to make longerterm consumption and investment decisions, contribute in different productive activities, and better manage risk and unpredicted shocks. All these factors will ultimately contribute to achieve an accelerated economic growth ${ }^{(1)}$.

2-3- Financial inclusion, income inequality, and poverty:

Financial inclusion is commonly considered as a crucial element to achieve inclusive growth. It permits the poorest segments of the population to ameliorate their economic situation, especially in developing countries, and eventually leads to poverty reduction.

The increased availability of financial resources to lower income groups enhances their access to education and self-employment, allows establishing businesses and productive activities and smoothen their consumption in confrontation of different shocks ${ }^{(2)}$.

(1) - Cyn-Young Park and Rogelio Mercado, "Financial inclusion, poverty, and income inequality in Developing Asia", ADB Economics Working paper series 426, January 2015, p.11.

- Asli Demirguc-Kunt, Leora Klapper, Dorothe Singer, and Peter Van Oudheusden, "The Global Findex Database 2014: Measuring Financial Inclusion around the World", Policy Research Working Paper 7255, The World Bank, 2014, p.1.

(2) - Cyn-Young Park and Rogello Mercado, Op.cit., p.11.

- Kalsoom Zulfiqar, Muhammad Chaudhary and Aribah Aslam, "Financial inclusion and its implications for inclusive growth in Pakistan". Pakistan Economic and Social Review, Vol, 54(2), 2016, pp. 298. 
Park and Mercado (2015), using a sample of 37 developing Asian economies, Jabir and others (2017), using a sample of 35 African countries, and Agyemang-Badu and others (2018), using a sample of 48 African countries, found a significant correlation between greater financial inclusion and lower poverty rates. They clarified that the main reason for this correlation is that financial inclusion of the poor allows them to access financial resources required to establish businesses, which raises their income and, in turn, reduces their poverty levels.

Moreover, financial inclusion can assist in lowering income inequality by disproportionately boosting the incomes of the poorest. Several studies (including Honohan (2007), Sahay and others (2015), Park and Mercado (2015) and Garcia-Herrero and Turegano (2018)) found that financial inclusion reduces income inequality. This was mostly due to loosening the credit constraints on poor citizens who lack credit history and collaterals.

\section{3 - Measurement of financial inclusion:}

Definitions and measurements of financial inclusion developed over the last years from classifying individuals and enterprises according to the simple access criteria, as either included or not, to the consideration of the financial inclusion as multidimensional. The adoption of a broader and multidimensional definition is necessary to move beyond the common assumption that inclusion will be achieved by simply offering access points. Instead, a more complete understanding of financial inclusion should assess how frequently clients use products and if these products meet their needs ${ }^{(1)}$.

(1) Thouraya Triki and Issa Faye, "Financial inclusion in Africa", African Development Bank (AFDB), Tunisia, 2013, p.31, http:JWWW.microtinancegateway.org/sites/default/files/mfg-en-paper-financial-inclusion-in-africa-2013.pdf (accessed March 3, 2019). 
Aiming to define a more comprehensive concept of financial inclusion, the Financial Inclusion Data Working Group of the AFI agreed on three main dimensions to measure and assess the degree of financial inclusion: access, usage and quality. These dimensions are broad categories into which indicators can be grouped without being restrictive. Detailed, these dimensions are:

(i) Access: This dimension is essentially concerned with the ability to use available financial products and services provided by formal institutions. A very basic proxy for access can be obtained from counting the number of open accounts in different financial institutions and estimating the percentage of adults that own an

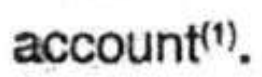

Assessing levels of access may require analysis of potential barriers to opening and using a bank account, such as cost and physical nearness of bank branches and points of services (POS). Indicators used to measure and assess the access level are numerous. For example: Number of bank branches $/$ ATMs per 100000 adults, percentage of adults who lack financial institution accounts for distance, cost or lack of documentation reasons, etc...

(ii) Usage: This dimension is concerned with more than the basic adoption of banks' accounts and the simple access to financial services and products. Indeed, it comprises the permanence and depth of financial service or product use. Measuring usage requires more details about the regularity, frequency and duration of use over time(2).

(1) Alliance for Financial Inclusion (AFI), "Financial inclusion measurement for regulators: survey design and implementation: policy paper?, February 2010, p.4, http:// www.afi-global.org/sites/ defaulvfiles/afi_policypaper_datameasurement_en.pdf (accessed March 25, 2019).

(2) Ibid, p.4. 
Examples of usage indicators include: percentage of adults who saved at/ borrowed from a financial institution in the past year, percentage of adults who used their accounts to receive wages or government transfers, percentage of adults using digital payments. Usage indicators also involve the percentage of firms I SMEs with a checking or saving account at a formal financial institution, percentage of firms / SMEs with a line of credit or a bank loan, percentage of firms / SMEs depending on banks to finance their investments or their working capital ...etc ${ }^{(1)}$.

(iii) Quality This component is devoted to the measurement of the relevance of the financial service or product to the consumer's needs. Quality embraces the consumer's experience, demonstrated in attitudes and opinions towards the services and products. Quality could be utilized to judge the nature and depth of the relationship between the consumer and the financial service provider, the possible choices and the levels of comprehension of these choices $^{(2)}$.

Quality indicators include the legal frameworks and institutional arrangements for financial consumer protection, disclosure and transparency and dispute resolution. They also involve the strength of credit reporting systems and the effectiveness of bankruptcy laws and collateral requirements in facilitating lending as well as the percentage of SMEs required to provide collateral

(1) -Global partnership for financial inclusion (GPFI), "G20 financial inclusion indicators", China, 2016, http//www.gpfi.org/sites/gpfilfiles/documents/G20\%20Financial\%20Inclusion\%20Indicators $\% 20 \% 282016 \% 20$ Update\%29.pdt (accessed March 25, 2019).

-The World Bank, "Global Financial Development Database (GFDD)", 2017, at: http:/Www. worldbank.org/en/publication/gfdr/gfdr-2016/data/global-financial-development-database (accessed March 25, 2019).

-The World Bank, "The Global Findex Database 2017", 2017, http://globalfindex.worldbank.org/ node?field_databank_country_target_jd=7 (accessed March 28, 2019).

(2) Alliance for Financial Inclusion (AFI), Op. cit., p.4. 
on their last bank loan. In addition, they include indicators for financial literacy and financial behavior (i.e. using savings for emergency funding)(1).

\section{4- Evolution of financial inclusion in Egypt:}

Although being present in Egypt since many years, financial inclusion was recently prioritized upon the presidential announcement in the Ninth International conference for Financial Inclusion at 2017. The following section of the study is mainly concerned about assessing the financial inclusion development in Egypt over the last years. This is addressed through measuring the access of individuals and enterprises to financial services and products provided by formal financial institutions, in addition to the usage and the quality of these services and products that would be useful for analytical purposes. As Egypt is included in LMIC and MENA groups, the current study compares the Egyptian results in the context of previously reported LMIC and MENA groups.

4-1- Adults with a financial institution account (account penetration):

According to the Global Findex database (the World's most comprehensive data set concerned about financial inclusion) published every three years since 2011 , the share of adults with a financial institution account increased in Egypt from \%9.7 in 2011 , to $\% 13.7$ in 2014 , then to $\% 32.1$ in 2017 . Even as the account ownership continued to grow, it remained far from the recorded average percentages in both LMIC and MENA groups. This

(1) -Global partnership for financial inclusion (GPFI), "G20 financial inclusion indicators", Op. cit., p.5.

- The World Bank, "The Global financial inclusion and consumer protection survey (FICP)", 2017, httpJ/Www.worldbank.org/en/topic/financialinclusion/briet/ficpsurvey (accessed March 29, 2019). 
average rose in the LMIC group from \%28.9 in 2011 to $\% 56.1$ in 2017 and rose for the MENA group from $37.6 \%$ in 2011 to 47.5 in \%2017 (Table 1).

Table 1: Ownership of financial institution accounts in Egypt, LMIC and MENA groups:

\begin{tabular}{|c|c|c|c|c|c|c|c|c|c|}
\hline & \multicolumn{3}{|c|}{ Year 2011} & \multicolumn{3}{|c|}{ Year 2014} & \multicolumn{3}{|c|}{ Year 2017} \\
\hline & Egypt & $\begin{array}{l}\text { LMIC } \\
\text { group }\end{array}$ & $\begin{array}{l}\text { MENA } \\
\text { group }\end{array}$ & Egypt & $\begin{array}{l}\text { LMIC } \\
\text { group }\end{array}$ & $\begin{array}{l}\text { MENA } \\
\text { group }\end{array}$ & Egypt & $\begin{array}{l}\text { LMIC } \\
\text { group }\end{array}$ & $\begin{array}{l}\text { MENA } \\
\text { group }\end{array}$ \\
\hline $\begin{array}{l}\text { Financial institution } \\
\text { account } \text { (\% age } \\
15+\text { ) }\end{array}$ & 9.7 & 28.9 & 37.6 & 13.7 & 40.6 & N.A & 32.1 & 56.1 & 47.5 \\
\hline $\begin{array}{l}\text { Financial institution } \\
\text { account, fernaje (\% } \\
\text { age } 15+)\end{array}$ & 6.5 & 23.4 & 28.3 & 9.2 & 34.5 & N.A & 27 & 51.7 & 38 \\
\hline $\begin{array}{l}\text { Financial institution } \\
\text { account, male (\% } \\
\text { age 15+) }\end{array}$ & 12.8 & 34.3 & 46.6 & 18 & 46.7 & N.A. & 37.2 & 60.1 & 56.9 \\
\hline $\begin{array}{l}\text { Financial institution } \\
\text { account, poorest } \\
40 \% \text { ( }(\% \text { age } 15+)\end{array}$ & 4.7 & NA. & 31.2 & 5.5 & 8.2 & NiA: & 20.3 & 124 & 32.5 \\
\hline $\begin{array}{l}\text { Financial insthution } \\
\text { account. richest } \\
60 \% \text { (\% age 15\%) }\end{array}$ & 13 & NA: & 42 & 19.1 & 20.8 & N.A. & 39.9 & 27.2 & 523 \\
\hline $\begin{array}{l}\text { Financial instiution } \\
\text { account, young } \\
\text { adults (\% } 15 \text {. } \\
24 \text { ) }\end{array}$ & 7.8 & 21.8 & 28.4 & 6 & 32 & N.A. & 12 & 46.9 & 34 \\
\hline $\begin{array}{l}\text { Finencial insthution } \\
\text { account. } \\
\text { adults }(5, \text { age } 25+)\end{array}$ & 10.6 & 31.5 & 41.7 & 17.3 & 43.9 & N.A. & 39.4 & 59.6 & 52 \\
\hline $\begin{array}{l}\text { Financial insthution } \\
\text { account, nural (\% } \\
\text { age 15-) }\end{array}$ & 5.6 & 26.5 & 27.8 & 10.5 & 39.9 & N.A. & 29.1 & 55.8 & 39.5 \\
\hline
\end{tabular}

Source: Data extracted from The World Bank, "The Global Findex Database 2017 ,"2017, http'/l globalfindex.worldbank.org/node?field_databank_country_target_ld =7 (accessed March ,30 2019).

Generally, the shares of female, rural, poorer and young adults with a financial institution accounts in Egypt improved over the years. However, they remained lower than the recorded averages in both LMIC and MENA groups; apart from an improvement in the $\% 40$ poorest and the $\% 60$ richest shares in Egypt compared with those in LMIC (Table 1). 
Moreover, inequalities persist and gaps widen. The improvements in the female shares over the years mask a growing gender gap. Men are more likely than women to own an account at a financial institution. While $\% 37.2$ of men in 2017 had an account, \%27 of women did. That gender gap widened over the years and rose from around six percentage points in 2011, to nine and 10.2 percentage points respectively in 2014 and 2017 (Table 1).

Among adults in the richest 60 percent, \%39.9 in 2017 had an account. Among those in the poorest 40 percent, only $\% 20.3$ did. That income gap between richer and poorer widened over the years, as it rose from around eight percentage points in 2011, to 13 and 19.5 percentage points in 2014 and 2017 respectively ( Table 1).

Young adults are over-represented among the unbanked. Although the increase of the young adults with a financial institution account shares from $\% 7.8$ in 2011 to $\% 12$ in 2017 , these percentages still remained low. Moreover, the gap between the young adults and the older shares widened from 2.8 percentage points in 2011, to 11.3 and 27.4 percentage points in 2014 and 2017 respectively ( Table 1 ).

4-2- Unbanked adults (barriers to formal account ownership):

Most of those adults with no financial institution accounts offered more than one reason when they were asked why they do not have one. Around $\% 83.2$ cited they have too little money to use an account (insufficient funds). Cost and lack of documentation 
were cited by around $\% 17.7$ and $\% 12.7$ respectively, while distance and distrust were cited respectively by $\% 7$ and $\% 5.2$ only (Figure 1 ).

Figure 1: Reasons for lack of financial institution accounts among adults:

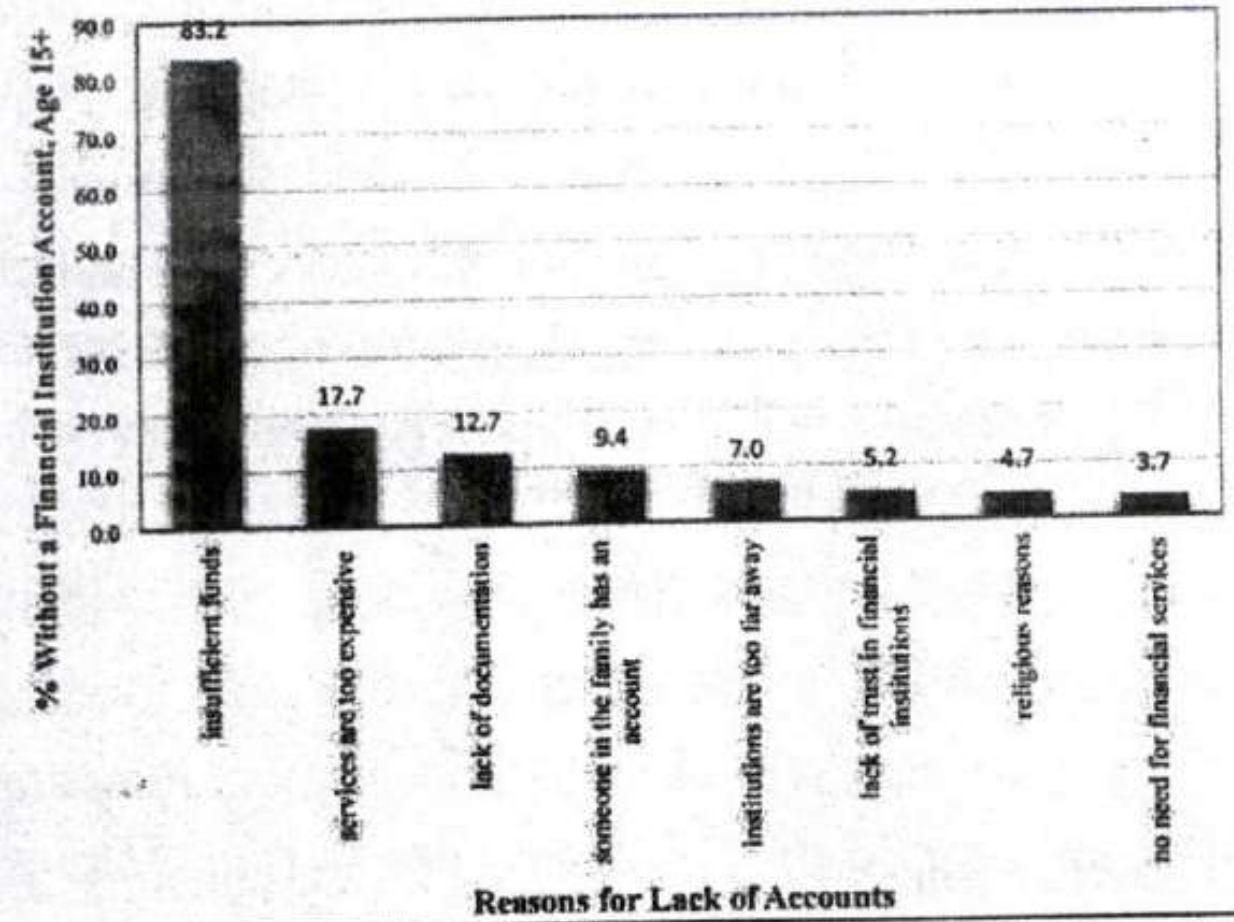

Source: Data extracted from: The World Bank, "The Global Findex Database 2017, 2017, http:1/globalfindex.worldbank.org/node?field_databank_country_target_ id=7 (accessed April 1, 2019).

Concerning the distance barrier, both the banking density (population in thousand per banking unit) and the village branches remained almost stable despite the slight increase in the banks branches' number in the last years (Table 2). 
Table 2: Number of bank branches, ATMs and POS (-2014 2018):

\begin{tabular}{|c|r|r|r|r|r|r|}
\hline & $\begin{array}{c}\text { June } \\
2014\end{array}$ & $\begin{array}{c}\text { June } \\
2015\end{array}$ & $\begin{array}{r}\text { June } \\
2016\end{array}$ & $\begin{array}{r}\text { June } \\
2017\end{array}$ & $\begin{array}{r}\text { June } \\
2018\end{array}$ & $\begin{array}{c}\text { Dec. } \\
2018\end{array}$ \\
\hline $\begin{array}{c}\text { Number of } \\
\text { branches }\end{array}$ & 3710 & 3766 & 3882 & 4009 & 4155 & 4220 \\
\hline $\begin{array}{c}\text { Number of } \\
\text { village branches }\end{array}$ & 1017 & 1017 & 1017 & 1017 & 1017 & 1016 \\
\hline $\begin{array}{c}\text { Banking } \\
\text { density* }\end{array}$ & 23.4 & 23.6 & 23.4 & 23.7 & 23.4 & 23.3 \\
\hline $\begin{array}{c}\text { Number of } \\
\text { ATMs }\end{array}$ & 6870 & 7855 & 9031 & 10701 & 11754 & 12200 \\
\hline $\begin{array}{c}\text { Number of } \\
\text { Pos }\end{array}$ & 51384 & 55876 & 64349 & 68630 & 72503 & 77479 \\
\hline
\end{tabular}

-Population in thousand per banking unit.

Source: Central Bank of Egypt (CBE) (2019a) "Monthly Statistical Bulletin", Issues N. 262 and 2019,268 .

This constancy definitely influences on financial services access. In contrast, the numbers of ATMs and POS have significantly increased over the last years, may be to balance the stagnation of number of banking branches mainly in villages (Table 2).

\section{4-3- Inactive accounts (no deposit or withdrawal):}

When moving from access indicators to usage indicators and shedding the light on the degree of accounts' usage, the situation differs. Although the share of adults with a financial institution account increased in Egypt from \%13.7 in 2014 to \%32.1 in 2017 , the degree of these accounts' usage decreased. Around $\% 21.7$ of those adults, according to year 2017 data, didn't make 
any deposits or withdrawals from their accounts in the previous year, compared with $\% 17.8$ only in year 2014. Obviously, the improvement in accounts' ownership was not associated with a comparable improvement in its usage. In addition, these inactive accounts figures are considered lower when compared to LMIC group (\%39.2) but higher if compared to that of MENA region $(\% 15.5)^{(1)}$.

4-4- Using accounts to receive wages or remittances or government payments:

As evident in table 3, despite a moderate improvement in the degree of using accounts to receive wages and also sending or receiving domestic remittances occurred over the last period, still there is a considerably greater preference of the cash transactions compared to using the financial institution accounts. This preference is similarly obvious when comparing Egypt to both LMIC and MENA countries.

This situation is much better when concerning about receiving government payments, as the percentage of these payments in cash to the total payment recipients, as recorded in 2017 , is $\% 14.9$ only compared to $\% 73.8$ for the payments into financial institution accounts. The Egyptian situation is better than the LMIC group (\%27 in cash and \%53.3 into financial institution accounts), but still did not reach MENA group levels (\%8.7 in cash and $\% 80$ into financial institution account) (Table 3).

(1) The World Bank, "The Global Findex Database 2017", Op. cit. 
Table 3: The percentages of adults who received wages, domestic remittances and government payments in cash or into

a financial institution account:

\begin{tabular}{|c|c|c|c|c|c|c|}
\hline & \multicolumn{3}{|c|}{2014} & \multicolumn{3}{|c|}{2017} \\
\hline & Egypt & $\begin{array}{l}\text { LMIC } \\
\text { group }\end{array}$ & $\begin{array}{l}\text { MENA } \\
\text { group }\end{array}$ & Egypt & $\begin{array}{l}\text { LMIC } \\
\text { group }\end{array}$ & $\begin{array}{l}\text { MENA } \\
\text { group }\end{array}$ \\
\hline $\begin{array}{l}\text { Received wages (\% wage } \\
\text { recipients, age }+15 \text { ) } \\
\text {-in cash only } \\
\text {-into a financlal institution } \\
\text { account }\end{array}$ & $\begin{array}{l}80.5 \\
18.6\end{array}$ & $\begin{array}{l}73.1 \\
24.7\end{array}$ & $\begin{array}{l}\text { N.A. } \\
\text { N.A. }\end{array}$ & $\begin{array}{l}65.1 \\
33.2\end{array}$ & $\begin{array}{l}60.4 \\
32.4\end{array}$ & $\begin{array}{l}42.3 \\
53.5\end{array}$ \\
\hline $\begin{array}{c}\text { Sent or received domestic } \\
\text { remiltances }(\% \text { senders and } \\
\text { recipients, age }+15) \\
\text {-in person and cash only } \\
\text {-into a financial institution } \\
\text { account } \\
\end{array}$ & $\begin{array}{c}74 \\
15.5\end{array}$ & $\begin{array}{l}53.2 \\
26.7\end{array}$ & $\begin{array}{l}\text { N.A. } \\
\text { N.A. }\end{array}$ & $\begin{array}{c}68.2 \\
24\end{array}$ & $\begin{array}{c}34.3 \\
40\end{array}$ & $\begin{array}{l}\text { N.A. } \\
\text { N.A. }\end{array}$ \\
\hline $\begin{array}{l}\text { Received government } \\
\text { payments (\% payment } \\
\text { recipients, age }+15) \\
\quad \text {-in cash only } \\
\text {-into a financial institution } \\
\text { account }\end{array}$ & $\begin{array}{l}\text { N.A } \\
\text { N.A }\end{array}$ & $\begin{array}{c}51.6 \\
38\end{array}$ & $\begin{array}{l}\text { N.A. } \\
\text { N.A. }\end{array}$ & $\begin{array}{l}14.9 \\
73.8\end{array}$ & $\begin{array}{c}27 \\
53.3\end{array}$ & $\begin{array}{l}8.7 \\
80\end{array}$ \\
\hline
\end{tabular}

Source: Data extracted from: The World Bank, "The Global Findex Database 2017 ,"2017, http:ll globalfindex.worldbank.org/node?field_databank_country_target_id=7 (accessed April 2019,3 ).

-5-4 Adults who saved at or borrowed from a financial institution:

People prefer to save semi-formally or informally than saving formally. The share of adults who save formally at a financial institution has always been low, specifically when compared to the share of adults using a saving club or person outside the family (Table 4). 
Table 4: The percentages of adults who saved or borrowed formally and informally:

$(\%$, age +15$)$

\begin{tabular}{|c|c|c|c|c|c|c|c|c|c|}
\hline \& & \multicolumn{3}{|c|}{ Year 2011} & \multicolumn{3}{|c|}{ Year 2014} & \multicolumn{3}{|c|}{ Year 2017} \\
\hline & Egypt & $\begin{array}{l}\text { LMIC } \\
\text { group }\end{array}$ & $\begin{array}{l}\text { MENA } \\
\text { group }\end{array}$ & Egypt & $\begin{array}{l}\text { LMIC } \\
\text { group }\end{array}$ & $\begin{array}{l}\text { MENA } \\
\text { group }\end{array}$ & Egypt & $\begin{array}{l}\text { LMIC } \\
\text { group }\end{array}$ & $\begin{array}{l}\text { MENA } \\
\text { group }\end{array}$ \\
\hline $\begin{array}{l}\text { Adults who saved: } \\
\text {-at a financial } \\
\text { Institution account } \\
\text {-using a saving club } \\
\text { or a person outside } \\
\text { the family }\end{array}$ & 1.7 & $\begin{array}{l}11.6 \\
7.1\end{array}$ & $\begin{array}{l}10.2 \\
\text { N.A. }\end{array}$ & $\begin{array}{r}4.1 \\
11.8\end{array}$ & $\begin{array}{l}14.4 \\
12.1\end{array}$ & $\begin{array}{l}\text { N.A. } \\
\text { N.A. }\end{array}$ & $\begin{array}{r}6.2 \\
16.2\end{array}$ & $\begin{array}{c}15.9 \\
13\end{array}$ & $\begin{array}{l}12.4 \\
\text { N.A. }\end{array}$ \\
\hline $\begin{array}{l}\text { Adults who saved: } \\
\text {-for old ages or to } \\
\text { start, operate, or } \\
\text { expand a farm or a } \\
\text { business } \\
\text { to start, operate, } \\
\text { or expand a farm or } \\
\text { business } \\
\text { for education ox } \\
\text { school fees }\end{array}$ & $\begin{array}{l}\text { N.A. } \\
\text { N.A. } \\
\text { N.A }\end{array}$ & $\begin{array}{l}\text { N.A. } \\
\text { N.A. }\end{array}$ & $\begin{array}{l}\text { N.A. } \\
\text { N.A. }\end{array}$ & 2.7 & $\begin{array}{l}11.7 \\
19.5\end{array}$ & $\begin{array}{l}\text { N.A. } \\
\text { N.A. }\end{array}$ & $\begin{array}{r}4.5 \\
\text { N.A. }\end{array}$ & $\begin{array}{l}12.8 \\
\text { N.A. }\end{array}$ & $\begin{array}{l}9.0 \\
\text { N.A. }\end{array}$ \\
\hline $\begin{array}{c}\text { Adults who } \\
\text { borrowed: } \\
\text {-from a financial } \\
\text { Institution or used a } \\
\text { credit card } \\
\text {-from family or } \\
\text { friend }\end{array}$ & $\begin{array}{l}\text { N.A. } \\
25.3\end{array}$ & 25.8 & 33.2 & 21.5 & 32.5 & N.A & 38 & 30.4 & 30.8 \\
\hline
\end{tabular}

Source: Data extracted from: The World Bank, "The Global Findex Database 2017,2017 , http://globalfindex.worldbank.org/node?field_databank_country_target_id=7 (accessed April $2019,1)$.

When compared with other countries' groups, two notices are important: First, Egypt status is far lower than LMIC and MENA groups. The share of adults who save formally is about half (or even lower) than that being recorded by both groups. Second, while the share of the adults who save formally in Egypt is lower 
than the informal share by 10 percentage points, it is higher than the informal share in LMIC group (Table 4).

Concerning saving patterns, the shares of adults who saved for old ages or to start, operate, or expand a farm or a business are faint over the years and compared with other countries' groups. As in LMIC and MENA groups, Egypt showed similar borrowing pattern (informal was preferred than formal borrowing). Family or friends is the most popular source of borrowing in Egypt (almost one third of adults reported having borrowed from family or friends) (Table 4).

\section{4-6- Mobile Money Accounts:}

The share of adults with a mobile money account raised from $\% 1.1$ in 2014 to $\% 1.8$ in 2017 . However, it is still lower than the share of $\% 5.4$ recorded in LMIC group ${ }^{(1)}$.

\section{4-7- Digital Transactions:}

There is a great improvement in the percentage of adults who made or received digital payments ${ }^{(2)}$ as the percentage increased from \%7.9 in 2014 to \%22.8 in 2017. Despite this improvement, this share is still lower than\%29.2 in LMIC and \%37.7 in MENA group $^{(3)}$.

4-8-Coming Up with emergency funds:

To measure financial resilience, the possibility of raising emergency funds was measured by asking respondents whether

(1) The World Bank, "The Global Findex Database 2017", Op. cit.

(2) The percentage of those who made or received digital payments is the percentage of respondents who report using mobile money, a debit or credit card, or a mobile phone to make a payment, or report using the internet to pay bills or to buy something online. It also includes respondents who report paying bills, sending or receiving remittances, receiving payments or government transters, or wages, or a public sector pension from or into a financial institution account or through a mobile money account.

(3) The World Bank, "The Global Findex Database 2017", Op. cit. 
it would be possible for them to come up with emergency funds or no. In turn, \%59.2 (in 2017) replied that it was not possible versus $\% 39.8$ agreed its possibility. This financial resilience is lower than that being reported in LMIC and MENA countries group. In both country groups, possible response was reported by $\% 49$ and $\% 46.7$, respectively(1).

Among those being able to raise funds in Egypt, \%65.4 of them had the main source of these emergency funds from family or friends, versus \%4.6 loan from a bank, employer or private lending and \%12.6 savings (Figure 2).

Figure 2: Sources of emergency funds:

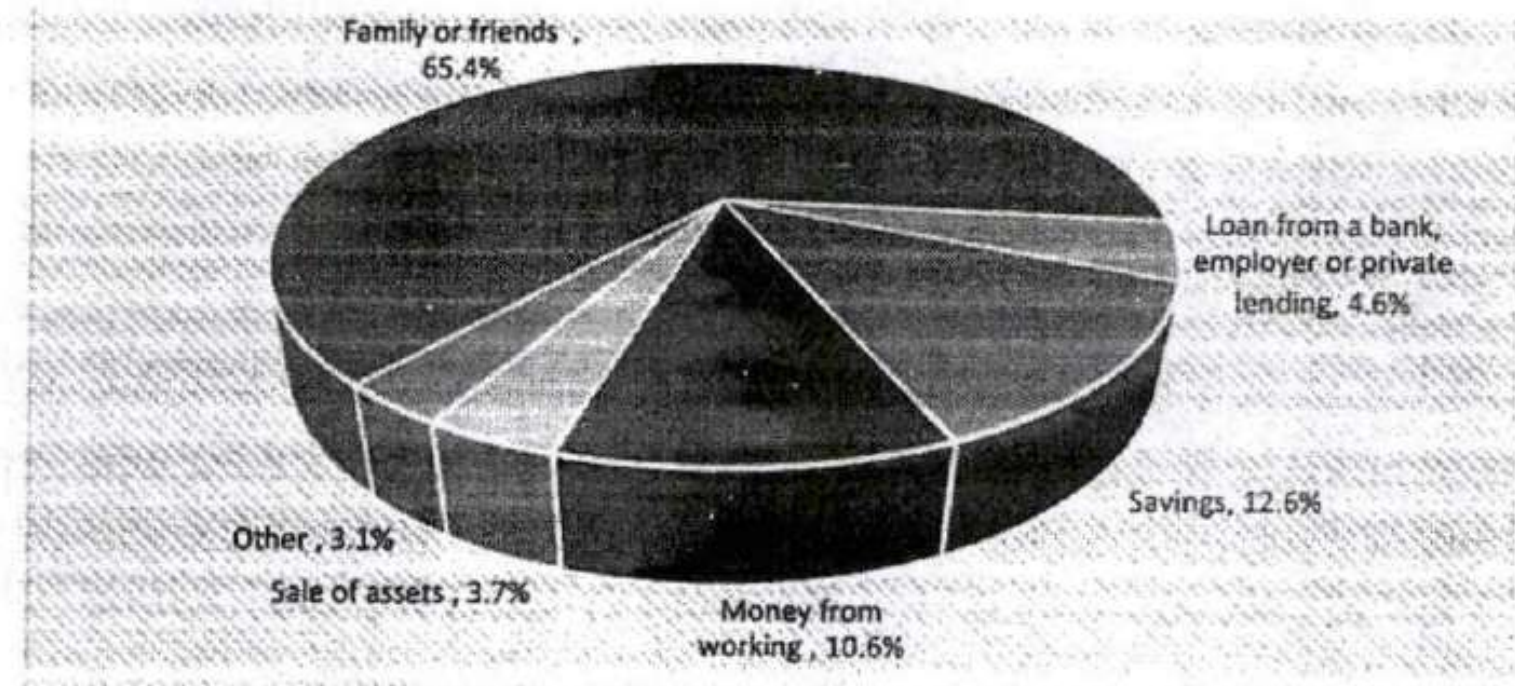

Source: Data extracted from. The World Bank. The World Bank. "The Global Findex Database 2017,2017 . http://globalfindex.worldbank.org/node?tield_databank_country_target_id=7 (accessed April 2019,5 ).

Focus on the "use of savings as a main source for emergency funding" indicator is important since it is considered as a quality indicator, as mentioned previously in section three of this research. In Egypt, while \%12.6 only of those able to raise funds in 2017 (as compared with \%15.6 in 2014) mentioned that they may depend

(1) Ibid. 
on savings to raise funds, $\% 20.6$ in LMIC group and $\% 17.1$ in MENA countries mentioned it. This confirms that Egypt is lower in quality in terms of this indicator as compared to LMIC and MENA groups $^{(1)}$.

\section{4-9- Disclosure requirements and dispute resolution:}

Information must be disclosed to consumers at the right time. Hence, timing of disclosure, as a quality indicator, is critical to facilitate comparison and provide sufficient time to consider the benefits and drawbacks of a given product before purchase. Concerning disclosure requirements, Egypt sufficiently meets most of the requirements covering the different stages as advertising, shopping, pre-contractual, contractual, and postcontractual stages ${ }^{(2)}$.

However, concerning dispute resolution mechanisms, they are still defective and unsatisfactory and lack some requirements concerning the standards for complaints resolution and handling as well as procedures for resolving customer complaints, timeliness of response by financial institution, record keeping of complaints... etc. ${ }^{(3)}$.

4-10-Firms' financial access to and usage of financial services and products:

Firms' access to finance and usage indicators in Egypt did not improve significantly over the past years. Even more, it declined in some occasions (as provided in table 5). Although the percentage of firms with a checking or saving account rose

(1) Ibid.

(2) The World Bank, "The Global financial inclusion and consumer protection survey (FICP)", Op. cit.

(3) Ibid. 
to reach 68.9 in 2016, (versus \%59.6 in 2013), it remained lower than the percentage recorded in MENA group at \%80.4) 2016) and even lower than the percentage recorded in Egypt in year \%74.2) 2008) (Table 5 and figure 3).

Table 5: Firms' access and usage indicators:

\begin{tabular}{|c|c|c|c|}
\hline Years & 2008 & 2013 & 2016 \\
\hline Percent of firms with a checking or savings account (\%) & 74.2 & 59.6 & 68.9 \\
\hline Percent of firms with a bank loan or line of credit (\%) & 17.4 & 6 & 6.6 \\
\hline $\begin{array}{l}\text { Percent of firms depending on banks to finance their } \\
\text { investments }(\%)\end{array}$ & 5.6 & 8.9 & 14.6 \\
\hline $\begin{array}{l}\text { Percent of firms depending on banks to finance their working } \\
\qquad \text { capital (\%) }\end{array}$ & 7.5 & 6.3 & 2.4 \\
\hline Proportion of investments financed by banks $(\%)$ & 3.5 & 5.2 & 7.9 \\
\hline Proportion of working capltal financed by banks (\%) & 3 & 2 & 0.9 \\
\hline Proportion of loans requiring collateral $(\%)$ & 84.5 & 92.4 & 98.5 \\
\hline Value of collateral needed for a loan ( $\%$ of the total loan) & 85.5 & 272.5 & 158.2 \\
\hline $\begin{array}{l}\text { Percent of firms whose recent loan application was rejected } \\
\qquad(\%)\end{array}$ & N.A & 42.2 & 20.9 \\
\hline $\begin{array}{l}\text { Percent of firms identifying access to finance as a major } \\
\qquad \text { constraint }(\%)\end{array}$ & 31 & 28.5 & 23.4 \\
\hline
\end{tabular}

Sources: -The World Bank, "Global Financial Development Database (GFDD", 2017, at: http'll www.worldbank.org/en/publication/gfdr/gfdr2016-/data/global-financial-development-database (accessed March 2019,29 ).

- The World Bank, "Enieiprise surveys. Custoni Query", at hitp/lwww enterprisesurveys.org/Custom-Query\#hReprtpreview (accessed April 2019 ,2).

Access of firms to external funding is notably limited in Egypt. Enterprise Surveys data show that $\% 6.6$ only of enterprises had a loan or a line of credit in 2016, compared with an average of \%29.4 in MENA countries group. Availability of credit is crucial to firms since it allows funding projects which otherwise would be constrained by the firm's limited pool of funds. In this context, 
it is important to highlight that \%20.9 of firms in 2016 failed to access external funding because their recent loan application was rejected. Although this percentage has improved as compared with 2013, it remained above the average in the MENA countries group that recorded \%10.6 only (Figure 3 ).

Collateral requirements play a significant role in external funding access and credit allocation. While the value of collateral to the value of the loan decreased in Egypt to reach \%158.2 in 2016 compared with \%272.5 in 2013 , the collateral incidence ( share of collateralized loans) increased in Egypt over the past years to reach \%98.5 of total loans in 2016. This proportion is above the average for MENA countries group (\%78.7) (Table 5 and figure 3 ).

Figure 3: financial access and usage indicators in Egypt and

\section{MENA group}

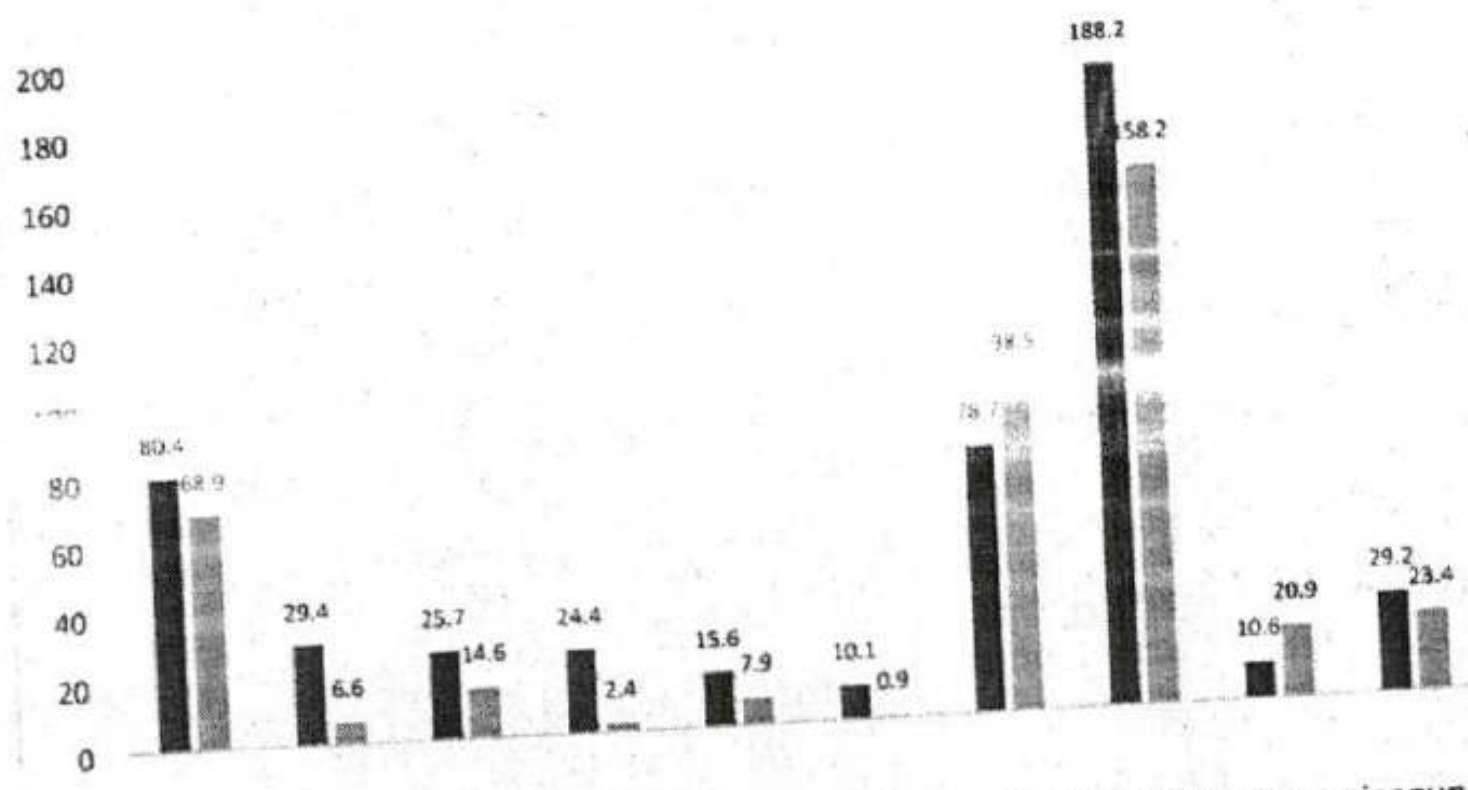

Source:The World Bank, "Enterprise surveys: Custom Query", at:http $/ /$ www.enterprisesurveys. org/Custom-Query\#hReprtpreview (accessed April 2, 2019). 
The percentage of firms depending on banks to finance their investments as well as the proportion of investments financed by banks increased over the past years but they remained less than the percentages achieved by the MENA countries group (Figure 3). Firms in Egypt depend heavily on financing investments internally. The percentage of firms' investments financed internally in Egypt in 2016 reached \%82.1 (versus \%7.9 financed by banks in the same year). Efficient financial markets diminish the dependence on internal funds or informal sources such as family and friends. Extravagant dependence on internal funds may indicate potentially inefficient financial intermediation(1).

In addition, the percentage of firms depending on banks to finance their working capital as well as the proportion of working capital financed by banks decreased over the past years to reach $\% 2.4$ and $\% 0.9$ respectively in 2016 . These percentages are so far away from its correspondents in MENA countries group that successfully achieved $\% 24.4$ and $\% 10.1$ respectively (Table 5 and figure 3).

\section{and products:}

Generally, SMEs indicators for access and usage of finance in Egypt improved over the past years (Table 6). Consequently, the percentage of SMEs identifying access to finance as a major constraint declined.

Regarding the percentage of firms depending on banks to finance their investments and the percentage of firms' investments

(1) The World Bank, "Enterprise Surveys: Egypt 2016 Country Profile", Enterprise Surveys, files/English/egypt-2016.pdf (accessed March 30, 2019) 
financed by banks, they improved over the past years for both small and medium firms (Table 6). However, still there is a great dependency on internal financing. The proportion of both small and medium firms investments financed internally recorded $\% 77.5$ and $\% 84.5$ respectively versus $\% 10.1$ and $\% 6.4$ respectively financed by banks ${ }^{(1)}$.

Table 6: SMEs' access, usage and quality indicators:

\begin{tabular}{|c|c|c|c|c|c|c|}
\hline \multirow[b]{2}{*}{ Firms' size } & \multicolumn{3}{|c|}{ Year 2013} & \multicolumn{3}{|c|}{ Year 2016} \\
\hline & Small & Medium & large & small & medlum & large \\
\hline $\begin{array}{l}\text { Percent of firms with a checking or } \\
\text { savings account }(\%)\end{array}$ & 50.2 & 73.1 & 85.6 & 58.3 & 87.5 & 93.9 \\
\hline $\begin{array}{l}\text { Percent of firms with a bank loan or line } \\
\text { of credit (\%) }\end{array}$ & 5 & 5.6 & 17.8 & 4.7 & 7.8 & 18.1 \\
\hline $\begin{array}{l}\text { Percent of firms depending on banks to } \\
\text { finance their investments }(\%)\end{array}$ & 11.7 & 3.1 & 13.5 & 22.2 & 7.7 & 5.7 \\
\hline $\begin{array}{l}\text { Percent of firms depending on banks to } \\
\text { finance their working capital }(\%)\end{array}$ & 4.6 & 7.2 & 19.5 & 2.1 & 2.4 & 4.9 \\
\hline $\begin{array}{l}\text { Proportion of investment financed by } \\
\text { banks (\%) }\end{array}$ & 6.1 & 2.5 & 8.3 & 10.1 & 6.4 & 4.0 \\
\hline $\begin{array}{l}\text { Proportion of working capital financed } \\
\text { by banks (\%) }\end{array}$ & 1.4 & 1.9 & 7.8 & 0.8 & 0.8 & 1.8 \\
\hline $\begin{array}{l}\text { Proportion of loans requiring collateral } \\
\qquad(\%)\end{array}$ & 88.3 & 99.9 & 93.7 & 100 & $\begin{array}{r}99.4 \\
0\end{array}$ & 94.1 \\
\hline $\begin{array}{l}\text { Value of collateral needed for a loan ( } \% \\
\text { of the total toan) }\end{array}$ & 296.1 & 316 & 156.4 & 146.7 & 172 & 141.4 \\
\hline $\begin{array}{c}\text { Firms whose recent loan application } \\
\text { was rejected }(\%)\end{array}$ & 30.1 & 75.8 & 48.1 & 9 & 32.9 & 14.7 \\
\hline $\begin{array}{l}\text { Firms identitying access to tinance as a } \\
\text { major constraint }(\%)\end{array}$ & 31.4 & 23.8 & 21.9 & 25.8 & 18.3 & 21.7 \\
\hline
\end{tabular}

- The World Bank, "Enterprise surveys: Custom Query", at. http://www.enterprisesurveys.org/ Custom-Query \#hReprtpreview (accessed April 2019,2)

-Firms are classified according to the number of employees to small firms ( $19-5$ employees). medium firms (99-20 employees) and large firms ( +100 employees).

(1) The World Bank, "Enterprise surveys: Custom Query", at: http:/www.enterprisesurveys.org/ Custom-Query \#heprtpreview (accessed April 2, 2019). 
The indicator of the value of collateral needed for a loan as a percentage of the total loan amount improved significantly and dropped from \%296.1 in 2013 to \%146.7 in 2016 for small firms. For medium firms, it also decreased from \%316 in 2013 to $\% 172$ in 2016.

Collateral requirements are often considered as critical obstacles for SMEs. The availability of assets that can be pledged may become a binding constraint on access to credit when loans need to be collateralized. That is why the percentage of SMEs required to provide collateral on their last bank loan is considered as a quality indicator - as mentioned previously in the third section of the research- as it reflects the tightness of credit conditions. In this context, it is important to highlight that $\% 100$ of small firms' loans and \%99.4 of medium firms loans are requested to provide collaterals by 2016. Finally, it is worth to be mentioned that still around one quarter of small firms report access to finance as a major constraint (Table 6).

\section{5 - Egypt's efforts and initiatives to enhance financial inclusion:}

Driven by the authorities' trust in the necessity of the inclusion of all segments of the society into the formal financial system, Egypt made serious efforts and adopted several measures to enhance the financial inclusion. As part of these efforts, many legal and regulatory reforms were performed, several partnerships were established, and multiple initiatives were enrolled. These actions included: 
5-1- Legal and regulatory reforms:

- The publication of the "Regulating Microfinance Activities Law": Since microfinance is one of the most effective financial sub-sector that serve the unbanked and underbanked in Egypt, many efforts have been executed to enhance it. On November 2014 , a law on regulating microfinance activity was published ${ }^{(1)}$.

The law aimed to regulate microfinance in a way that develop microfinance professional standards and supervise the microfinance companies to ensure transparency, efficiency and risk management. It also aimed to encourage and regulate the establishment of microfinance companies and expand financial services. It allowed civil associations and institutions to contribute in the establishment of companies that practice microfinance but prohibited them from receiving any deposits.

In the context of this law, an agreement between the CBE and the Financial Regulatory Authority (FRA) has been signed to potentiate the cooperation between them to support financial inclusion and microfinance activity in Egypt. Accordingly, microfinance is provided to finance economic activities or services or commercial purposes with the value determined by FRA and it shall not exceed hundred thousand EGP(2).

The $\mathrm{CBE}$, through the microfinance law, stimulated banks to lend to microfinance institutions (MFls) and non-governmental organizations (NGOs) providing microfinance. The amount of credit assigned to microfinance granted by banks, NGOs, and

(1) Al-Waquaa Al-Mariya, "The presidential decree No.141 of 2014 on regulating microfinance activity", Issue No. 46, November 2014 (in Arabic).

(2) The given value can increase by $5 \%$ year by a decree issued by the Prime Minister on the proposal of the Board of Directors and in concordance with the economic conditions and the requirements. 
private enterprises in Egypt augmented over the last years. It reached 15.6 billion EGP by the end of the Q2 of 2018 (compared with 7.5 billion EGP in the same quarter of 2017). Microfinance client beneficiaries reached 2.9 million by the end of the Q2 of ' 2018 (compared with 2.1 million customers in the same quarter of 2017$)^{(1)}$.

- The establishment of the "National Council for Payments (NCP)": In February 2017, the "NCP" was instituted according to the Presidential Decree No. 89 of $2017^{(2)}$. By this decree, the national council was tasked to achieve the following:

Reduce the use of cash and enhance the use of electronic payment mechanisms.

Develop national payments systems and their oversight mechanisms.

Ameliorate financial inclusion to integrate the greatest number of citizens and firms in the banking system and to merge the informal sector into the formal one.

Reduce the cost of fund transfers and provide protection to the consumers of electronic payment systems.

To accomplish these tasks, the decree offered the council the authority to take decisions to the concerned entities regarding the development of the general structure of the national payments systems and their supervisory and legal regulatory frameworks. Also, the NPC was authorized to warrant complementarity and

(1) Alliance for Financial Inclusion (AFI), Central Bank of Egypt (CBE) and Bridging the Gap, "Integrating gender and women's financial inclusion into national strategies", FIS Working Group Guideline Note, No. 27, April 2019, p.9, at: http:IMWW, afi-global.erg/sites/defaulvfiles/publications/2019-04/AFL_Egypt\%20gender AWL digital.pdf (accessed April 5, 2019).

(2) Al-Waquaa Al-Masriya, "Presidential decree N.89 of 2017 to establish the National Council for Payments", Issue N.5 A, February 13, 2017 (in Arabic). 
harmonization between the various governmental initiatives and entities involved in the national payment field.

Actually, the NCP has already elaborated certain decisions and recommendations. Revision of the rules and regulations, as well as the different mechanisms for the opening of accounts for mobile payments was a primary focus that had the immediate attention of the council. During its first meeting in June 2017, the council decided to free customers from the expenses of opening new accounts for mobile payment services for one year from the decision's date of issuance and further reduced the costs of mobile payment services by half for six months. These actions extended to March 2019 in the NPC's third meeting at September 2018. In turn, mobile accounts augmented from 10.5 million accounts in May 2018 to 12.9 million accounts at February 2019(1).

In its consecutive meetings, the NPC prepared a draft law for e-payment services that aimed to transform Egypt to a cashless economy depending mainly on an electronic system to execute financial transactions. The final version of the draft law was submitted to the parliament that approved it.

- The promulgation of the "E-payment Services Law No. 18 of 2019": In March 2019, a new law has been approved by the Egyptian parliament to promote e-payment and enhance financial inclusion. The Egyptian president approved this law in a decree that was published at 16 April 2019.

(1) -Alliance for Financial inclusion (AFI), the Central Bank of Egypt (CBE) and Digital Financial Services (DFS) Working Group, "Financial inclusion through digital financial services and Fintech: The case of Egypt", August 2018, p.5, at: http:// www.afi-global.org/sites/default/iles/publications/2018-08/AF1_Egypt_Report_AW_digital.pdf (accessed April 7, 2019).

-Alliance for Financial Inclusion (AFI), Central Bank of Egypt (CBE) and Bridging the Gap, Op.cit., p.8. 
Accordingly, government institutions, state owned firms, and public legal persons must use electronic payment systems and equip non-cash means of payments to their customers to collect their financial receivables and dues. Private companies and entities must provide all payments to employees, contractors and service providers by e-payment systems. Citizens will have to use e-payment system to pay for all government services and state fees. Civil society groups, must use e-payment to receive donations or funding. Violators could pay fines of two - five $\%$ of the paid amount ${ }^{(1)}$. To achieve that, a large number of POS were installed at government institutions.

- The approval of a new version of the "Mobile Payment Services Regulations": In 2013, a new service started in the Egyptian market and allowed mobile-phone users to carry out money transfer as well as payment transactions by mobile through banking channels. After three years of the introduction of mobile payment services, the number of subscribers reached 6.2 million.

In November 2016, the CBE approved a new version of the "Mobile Payment Services Regulations". This opened the door to mobile financial services including bill payments, payroll, collection of microfinance installments, transfer and reception of funds and remittances, as well as government payments. According to new regulations, banks were able to employ agents to verify customer identities. Also, it became possible for cross-border remittances to be performed through mobile accounts. These new regulations pushed telecommunications companies and banks to make their platforms schemes interoperable.

(1) Al-Waquaa Al-Masriya, "The law N.1qwwqqqqqqqqqqqqqqqqq of 2019 about the regulation of the usage of electronic payment", Issue N.15 (B), April 16, 2019 (in Arabic). 
In November 2017, the CBE further approved increasing caps on cash withdrawals and depositing using mobile-phone cash transfer services. The limit raised to 50000 EGP per month and 10000 EGP per the daily transaction, while it was formerly 5000 EGP per month and 3000 EGP per day.

As a result, the mobile payment growth rate from February 2018 to February 2019 raised to \%35.6. Mobile payment money in circulation from February 2018 to February 2019 was 14 billion EGP (versus 4.95 billion only in year 2017), with an estimated monthly transaction value of around 1.4 billion EGP(1).

- The strengthening of the "Financial Consumer Protection Regulations": The CBE approved the establishment of an independent central administration to protect and safeguard consumers of financial services by managing the implementation of consumer protection regulations. The regulations promoting the banking sector consumers protection principles have been approved by the CBE Board in February 2019 following consultation with banks, relevant national stakeholders and international institutions ${ }^{(2)}$.

\section{5-2- Agreements and memberships:}

- The signature of the Egyptian Government agreements with Visa and MasterCard: In March 2016, the Egyptian government and Visa signed a Memorandum of Understanding

(1) - Alliance for Financial Inclusion (AFI), the Central Bank of Egypt (CBE) and Digital Financial Services (DFS) Working Group, Op. cit., p.5.

-Alliance for Financial Inclusion (AFI), Central Bank of Egypt (CBE) and Bridging the Gap,
p.cit., p.7.

(2) Central Bank of Egypt (CBE), "Circular dated 19 February 2019 regarding banking sector consumer protection", 2019, at:http/NWWW.cbe.org.eg/en/Pages/HighlightsPages/Circular-dated-19-February-2019-regarding-Banking-Sector-Consumer-Protection.aspx (accessed April 7, 2019). 
(MoU) to enable electronic digital payment of government' subsidies to 22 million Egyptian families.

Previously, the Egyptian government and MasterCard signed a MoU that sought to expand financial services to 54 million Egyptians through a digital national ID program. As part of this agreement, MasterCard worked with the government to develop a digital Id program that is able to link citizens' national ID to the national mobile money platform. This could permit Egyptians to pay for numerous services such as government fees, merchant purchases, mobile bills and domestic remittances by a cashless program. In addition, social benefits and salaries are electronically handed out through the card(1).

-The membership of regional and international institutions: Regionally, the CBE is a member of the Council of Arab Central Banks Governors of the Arab Monetary Fund (AMF). Additionally, the $\mathrm{CBE}$ is an active member of the Financial Inclusion Taskforce (FITF), in a step towards strengthening the financial inclusion and stratifying its agenda with local needs and global trends.

Internationally, the CBE joined the AFI in July 2013. The AFI is considered as the main network to exchange technical and practical experiences among the different member states in the field of financial inclusion. Subsequently, this helped to pose financial inclusion at the top of the CBE's policy agenda.

In July 2017, Egypt was chosen, along with China and Mexico, as a model country in a new Financial Inclusion Global Initiative that was launched by the World Bank Group. The three-year

(1) Mona Beckzada, "Engendering the banking financial institutions in Egypt to enhance financial inclusion", 2018, Academia, at: http//WWW academia. $\theta d u / 37241907 /$ Engendering the banking financial institutions in Egypt to enhance financial_inclusion (accessed April 8, 2019). 
initiative goals to support access to financial services and develop digital finance(1).

5-3- Initiatives, programs and strategies:

- The launch of "The National Strategy for Financial Literacy": To propagate financial awareness and education, the CBE, in 2014, launched the National Financial Literacy Committee, which is led by the Egyptian Banking Institute (EBI) -the CBE's training arm - with the participation of different pertinent stakeholders to develop the "National Strategy for Financial Literacy u. In order to develop and potentiate financial education in Egypt, many campaigns have been proceeded with around seven million beneficiaries of these campaigns across 27 governorates (in the period from year 2013 to 2018).

- The amendment of "the mortgage finance initiative": In June 2017, the CBE modified the mortgage finance initiative targeting low- and middle-income beneficiaries, which was issued in February 2014. The new 2017's version changed the interest rates and income levels and included a new income branch (table 7).

(1) Center for International Private Enterprise (CIPE), Thebes Consultancy, The Federation of Egyptian Industries and The Federation of Egyptian Banks, "Facilitating bank account transactions: A step towards financial inclusion", 2017, at: http/hwwwecipe-arabja.org/ files/pdt/Demecratic Governance/Banks Accounts for_Financia! Inclusion English_WEB.pdi 
Table7: The 2014 and 2017' mortgage finance initiatives:

\begin{tabular}{|c|c|c|c|c|c|c|}
\hline & \multicolumn{2}{|c|}{ Low income } & \multicolumn{2}{c|}{ Middle income } & \multicolumn{2}{c|}{$\begin{array}{c}\text { Above (or distinctive)- } \\
\text { middle income }\end{array}$} \\
\hline & $\begin{array}{c}2014 \text { 's } \\
\text { initiative }\end{array}$ & $\begin{array}{c}2017 \text { 's } \\
\text { initiative }\end{array}$ & $\begin{array}{c}2014 \text { 's } \\
\text { initiative }\end{array}$ & $\begin{array}{c}2017 \text { 's } \\
\text { initiative }\end{array}$ & $\begin{array}{c}2014 \text { 's } \\
\text { initiative }\end{array}$ & $\begin{array}{c}2017 \text { 's } \\
\text { initiative }\end{array}$ \\
\hline Interest rate (\%) & 7 & $7 \cdot 5$ & 8 & 8 &. & 10.5 \\
\hline $\begin{array}{c}\text { Maximum } \\
\text { Monthly } \\
\text { Income } \\
\text { (EGP) }\end{array}$ & $\begin{array}{c}\text { Less than } \\
1750\end{array}$ & $\begin{array}{c}\text { Less than } \\
2100\end{array}$ & $\begin{array}{c}8000 \text { for } \\
\text { individual } \\
10000 \text { for } \\
\text { household }\end{array}$ & $\begin{array}{c}10000 \text { for } \\
\text { individual } \\
14000 \text { for } \\
\text { household }\end{array}$ & $\cdot$ & $\begin{array}{c}15000 \text { for } \\
\text { individual } \\
20000 \text { for } \\
\text { household }\end{array}$ \\
\hline
\end{tabular}

Source: Central Bank of Egypt (CBE), “CBE initiatives”, www.cbe.org.eg/en/Pages/CBElnitiatives. aspx (accessed April 2019,10 ).

When the 2017's initiative was released, the CBE kept the fund allocated to the initiative as 10 billion EGP. Four months later, it decided to augment the funds allocated to 20 billion EGP.

- The launch of the "Small and Medium Enterprises Program": In January 2016, the CBE started a program to finance 350 thousand SMEs with 200 billion EGP through the banks over four years with an interest rate of $\% 5$. The CBE guided the banks to increase the rate of loans directed to the sector to $\% 20$ of their total portfolios within the following 4 years (by year 2020). Additionally, every bank should establish specialized units to provide financial services to these enterprises. To mention, since the launch of the program until June 2017, around 49 billion EGP were injected to finance SMEs ${ }^{(1)}$.

- The launch of the "Strengthening Financial Coverage, Censorship and Supervision of Banks in Egypt program": In November 2018, the CBE commenced, in cooperation with the European Union and the German Embassy in Cairo, a program to empower financial inclusion. This program attempted to

(1) Ibid. 
strengthen the regulatory framework of banking and support the Central Bank's efforts to build a comprehensive national database to assess the levels of financial inclusion. It represented a part of "Enhancing the Access of SMEs to Financial Services" program in Egypt that was funded by the German Federal Ministry for Economic Cooperation and Development. This last one looked for enhancing the access of SMEs to different banking services as well as non-bank financial services, such as equity financing and SME's insurance.

- The institution of "The Centralized Financial Inclusion Data Hub": In 2018, the CBE started to formulate a strategy for collecting and analyzing financial inclusion data. A data committee has been organized to systematically collect and analyze the data. This aimed to better understand the characteristics of financial services access and usage, create a baseline to track progress towards financial inclusion goals and finally establish an evidence base for more suitable and targeted policy interventions.

To achieve these goals, the CBE organized "the Centralized Financial Inclusion Data Hub" to collect data from both, the demand and supply sides, from all financial institutions through a unified banking sector network depending on the national ID. The first phase, which is already achieved, is for "one time data" that included all banks' current individual customers with their accounts, cards and mobile wallets. The second phase is dedicated for "periodic data" that includes new data or statuschange data that varies from the previously delivered data.

These efforts will be complemented by the full-fledged demand-side and supply-side mapping exercise conducted in 2019 covering both households and micro, small and medium 
enterprises (MSMEs) and the informal sector. The results will help policy makers to draw effective policy interventions and help the private sector to understand the needs of the targeted segments.

- The development of the "Egypt Vision 2030": All the previously mentioned efforts have been complemented by the Egyptian Government's own ambition and commitment towards achieving financial inclusion, as envisioned in the "Sustainable Development Strategy (SDS): Egypt Vision 2030" document, published in February 2016. Economic development policies cited in this vision insured on enhancing financial inclusion through increasing credit provided to the private sectors and SMEs as well as boosting rural financial inclusion. Financial inclusion is a principal focus of the country's SDS, given its potential to create more opportunities for inclusive growth, sustain financial and social stability, and achieve else national goals.

6 - Key messages and recommendations:

The analysis of the access, usage and quality of financial services used by individuals or enterprises clarified that Egypt lags behind other LMIC and MENA region countries in many aspects. Despite the wide range of measures and efforts -described in the previous section- performed over the last years in order to enhance financial inclusion in Egypt, a number of challenges remain. Further efforts need to be accomplished to face these challenges and to build on the initial results that are recently achieved. The main challenges and their corresponding needed efforts are as follows:

First: Despite the improvement in financial inclusion indicators in Egypt over the last years, many individuals are still excluded from the formal financial system. According to year 2017 Findex 
data, \%67.9 of Egyptian adults remain unbanked. Distance, lack of documentation and cost were among the obstacles that prevented adults from owning the accounts.

Adults living in rural or remote communities face logistical and financial difficulties in reaching banks. The banking density and the number of branches in villages remained almost stable over last years. Requirements for establishing new branches need to be re-considered. Relaxing the requirements for bank expansion should allow them to geographically expand and would facilitate access.

According to the Egyptian Banking Law and its executive regulations, to establish a new branch, the mother bank needs to meet the core capital allocation requirement for establishing new branches (20 million EGP for each branch). It is recommended to reduce this allocation requirement to promote the establishment of new branches.

Additional actions could be taken in order to overcome or address the distance obstacle. In this regard, the Indian experience is very beneficial ${ }^{(r)}$. India adopted different bank-led models to cover its 640 districts including around 600000 villages. The "lead bank" model assigned each district to different banks, either public or private. The leader bank acted as a consortium leader and coordinated the banks efforis in the district certainly concerning branch expansion and credit planning ${ }^{(2)}$.

(1) To be mentioned that India, before commencing its financial experience, had similar challenges as Egypt. India was considered one of the most popular cash-reliant economies. It was estimated that $98 \%$ of all transactions were in cash and $50 \%$ of the population were unbanked. However, in less than a decade, India succeeded to become one of the leading economies on financial inclusion. Percentage of adults with a financial institution account increased from $35.2 \%$ in 2011 to $52.8 \%$ in 2014 then to $79.8 \%$ in 2017 . The World Bank; "The Global Findex Database 2017", Op. cit.

(2) Hema Gwalani and Shilpa Parkhi, "Financial inclusion: Building a success model in the Indian context", Procedia Social and Behavioral Sciences, N.372-378, EISevier, May 2014, at:http'll WWW researchgate.net/publication/262641575 Financial Inclusion _-Building_a_Success_ Model_in_the_Indian_Context (accessed April 13, 2019) 
Institutionally, this banking model allowed banks to use intermediaries like Business Correspondents (BCs) and Business Facilitators (BFs) to provide financial services. The $\mathrm{BCs}$ are retail agents, either organizations or individuals (as MFIs, NGOs, corporate companies, small shops, etc...) who, according to the model, were allowed to conduct banking business as agents of the banks at different locations that are deprived of bank branches and ATMs. To accomplish the transactions, they utilized various technologies as POS devices and mobile phones. BFs can refer clients, pursue the clients' proposals and facilitate the bank to carry out its transaction. In contrary to BCs, BFs cannot transact on behalf of the bank. Adopting the different bank led approaches increased the banks' opportunities to reach out to the unbanked populations $^{(1)}$.

In addition, Indian banks were instructed by the Reserve Bank of India to allocate at least 25 percent of their total number of branches that are planned to open during the year in un-banked rural centers ${ }^{(2)}$. In this context, the CBE may determine a similar 25 percent of the total number of banks' branches to be opened in villages to surpass the distance and mobility limits.

Second: Concerning the "cost barrier" obstacle, and since cost represented a major obstacle for financial institution accounts ownership cited by $\% 17.7$ of the unbanked adults, it is recommended that certain groups, such as university students and low income citizens, be exempted from account opening fees. This will overcome the cost barrier and promote the financial inclusion.

(1) - College of Agricultural Banking Pune (CAB), Access Development Services and Consultative Group to Assist the Poor (CGAP) "Business Correspondents and facilitators: Pathway to financial inclusion?", at:http://inclusivefinanceindia.org/userfile/files/thematic_retreats.pdf (accessed April 13, 2019).

- Hema Gwalani and Shilpa Parkhi, Op. cit.

(2) Mona Beckzada, Op, cit. 
Third: Concerning the "lack of documentation" obstacle, requirements for opening an account need also to be eased. A relaxed and simplified "Know Your Customer" (KYC) norms, especially for small accounts, needs to be fostered. Applying full KYC actual rules make opening an account a complex procedure because of the documents required.

The required documents to open an ordinary account, as the place of residency and the place of work verification documents, aggravate the financial exclusion of those who are engaged in informal work arrangements or those deprived of a permanent place of residence. These documents could be replaced by a personal identity document and a written self-declaration clarifying the nature of the individual's business/ employment (in case of informal workers).

Financial services that provide wel! defined and limited services (e.g. low risk transactions, small value) to particular categories of customers (e.g. low income customers) associated with simplifications of KYC rules have the potential to enhance access to financial services.

Fourth: Measures and policies to tighten the gender gap have to be adopted. Breaking down the gender-insensitive banking is a necessity. This could be achieved through allocating sufficient percentages for supporting women in the government's priority sector lending programs, developing need-based credit packages, setting up special women branches and units.

The CBE may direct the banks to determine a specified percentage of their total portfolios to provide credit to women. So, banks will replace their credit plans with gender sensitive and needs' based loans for women. CBE needs to enroll diagnostic 
studies and further consultations to well understand the differences between men and women's access, barriers, needs, etc... These consultations would guide CBE to accomplish the regulatory reforms needed and to work with banks on developing innovative products that are suitable for women.

Fifth: Technological development and the use of digital platforms have several benefits to financial inclusion as they help to overcome mobility restrictions, reduce transactions costs and enhance transparency. For example, switching from cash to digital payments can diminish corruption and ameliorate efficiency. In India, the leakage of funds for pension payments declined by $\% 47$ when payments were paid through smart cards instead of cash.

Mobile money allows extending access to financial services to difficult-to-reach individuals as well as small businesses at a low cost and risk. A study about financial inclusion in Kenya concluded that access to mobile money services resulted in considerable benefits, certainly for women. These services allowed womenheaded households to augment their savings by more than a fifth. They enabled women to quit farming and start business or retail activities and reduced women-headed households' poverty by $\% 22$. They helped people to manage financial risks by making it easier to collect money from faraway friends and relatives at harsh periods. When confronted with an unpredicted drop in income, mobile money users did not decrease their spending, while non-users as well as users with unease access to mobile money networks dropped their purchases of food and other items by ${ }^{(1)} \% 10-7$.

(1) Asli Demirguc-Kunt, Leora Klapper, Dorothe Singer, Saniya Ansar and Jake Hess (2018) "The Global Findex Database 2017 Report: Measuring Financial Inclusion and the Fintech ResoIution". The World Bank, 2018, p.1, at: http://openknowledge.worldbank.org/handle/10986/29510 (accessed April 15, 2019). 
In addition, mobile money services can diminish the cost of receiving payments. In Niger, converting the monthly government payments of social benefits from cash to mobile phones saved twenty hours on average in overall recipients' travel and waiting time to receive payments. Benefits extended to the administration costs that were also reduced by ${ }^{(1)} \% 20$.

More efforts need to be executed to enhance the use of mobile money as the share of Egyptian adults with mobile money accounts in Egypt has only reached \%1.8 in 2017. Also, expanding the electronic banking services is widely recognized as a step towards better financial inclusion by reducing the costs and efforts of providing such services. However, according to the CBE and its regulations, financial services provided through electronic communication channels limit customers to only perform the following: i) Access to information related to the services provided by banks: ii) Access to a limited number of services, such as updating their information, obtaining information related to their current balance and transactions and submitting requests for credit. iii) Request the bank to transfer funds ${ }^{(2)}$.

A quick look at the services above listed reveals that electronic or online banking is limited in Egypt to a short list of services, while the remaining wide range depends on paperwork and necessitates customer's face-to-face interaction with the bank. It is recommended to expand the range of financial services that could be achieved electronically, to allow users to create deposits, make withdrawals and apply for limited credit facilities and ioans through electronic forms. Banks can provide branchless banking through delivering their financial services by an online platform with a possible chat facility.

(1) Ibid, p.2.

(2) Center for International Private Enterprise (CIPE), et al., Op. cit., p.26. 
Sixth: Banks have high interest rates and tough collateral requirements. As a result, individual's preference to borrow from family or friends is higher than borrowing from banks. By the same, firms mostly depend on financing investments internally than using formal credit.

Collateral requirements play a considerable role in firms' external funding access. While a high collateral incidence may reflect systems that are based on relatively prudent lending practices, higher collateral ratios are often associated with less credit availability. Since movable assets such as equipment, machinery, or receivables represent a substantial share of firms' assets, a collateral regime that allows for movable assets has a tendency to facilitate financial access. Egyptian banks showed reluctance to accept such movable assets as collateral and preferred land or real estate instead. Subsequently, Egypt is considered as one of the lowest MENA region countries concerning the share of loans collateralized with movable assets ${ }^{(1)}$. So, in order to facilitate financial access and credit availability, this issue must be reconsidered and banks need to show more flexibility and accept a higher share of movable assets.

Seventh: Consumer protection measures need to be improved in order to provide customers with higher confidence and raise their protection against risks, fraud, and criminal activities. The "Financial Consumer Protection Unit" activities and powers need to expand. According to the Global and Financial Inclusion and Consumer Protection (FICP) survey, the unit lacks the activities of market monitoring (such as providers' advertisements and

(1) European Bank for Reconstruction and Development, The European Investment Bank, and The World Bank, "What's Holding Back The private sector in MENA: Lessons from the Enterprise Survey", 2016, at: http:/WWW.enterprisesurveys.org/reports/ /media/GIAWB/EnterpriseSurveys/ Documents/Misc/MENA-Business-Climate-2016.pdf (accessed April 14, 2019). 
websites), interviews, focus groups and research with consumers. In addition, it lacks the powers of requiring providers to withdraw misleading advertisements, issuing public notice of violations, revoking or recommending to revoke license and issuing administrative sanctions to senior management(1).

Eighth: Although MFIs have the authority, according to the "Regulating Microfinance Activities Law", to lend small enterprises, yet they have higher interest rates than banks (up to \%18). These rates actually discourage small enterprises to borrow from $\mathrm{MFIs}^{(2)}$.

Moreover, while the CBE and the FRA, in the context of the mentioned law, signed an agreement to enhance cooperation between them in supporting financial inclusion, this agreement has not resulted in a unified financial inclusion strategy with specific targets.

Ninth: Post offices in Egypt can play a leading role in advancing financial inclusion due to their outreach and positioning. They are relatively more likely than traditional financial institutions (such as commercial banks) to provide accounts to people who are most probable to be financially excluded such as the poor and less educated ${ }^{(3)}$. Egyptian posts provide services such as postal, e-government and financial services. There are around 4000 post offices in Egyptserving an average of 23 thousand persons/month/ post office ${ }^{(4)}$. Yet they are limited to specific financial services such as opening current and saving accounts. It is further possible to open a cooperate saving account where account holders are also

(1) The World Bank, "The Global financial inclusion and consumer protection survey (FICP)". Op. cit.

(2) Mona Beckzada, Op. cit.

(3) Jose Anson, Alexandre Berthaud, Leora Klapper and Dorothe Singer, "Financial Inclusion and the role of post office". Policy Research Working Paper wps6630. The World Bank, October 2013 , p.2, at: http///documents.worldbank.org/curated/en/680321468163464611/pdt/WPS6630. pdf

(4) Mona Beckzada, Op. cit. 
addressed to life insurance coverage, in addition to the advantage of benefitting from a special credit interest rate on their savings for a fixed monthly fee. Moreover, people can pay bills for certain fees, transfer money as a "Hewala", and request bank check collection. Master/Visa debit cards are also available to posts customers enabling them to access their accounts through Post's ATM network and POS available in Egypt in addition to any ATM or POS that accepts Visa/Master cards worldwide.

Unfortunately, little is known about the type of clients that Egyptian post offices reach through their provision of financial service and what impact do they have. It is still an area that requires worth exploration.

Tenth: Finally, more efforts concerning facing financial illiteracy must be approached. It is mandatory to build awareness through financial literacy and education. Also, it is important to conduct financial education programs that target the least educated to enable them to develop a reasonable comprehension about the formal language used by banks and the different financial services. In addition, financial terms and concepts could be embedded in school curriculums.

\section{Conclusion:}

Financial inclusion is receiving an increased attention for its potential beneficial financial and economic impacts. It can enhance financial stability, promote economic growth, reduce income inequality and alleviate poverty. Driven by the Egyptian authorities' trust in the importance of the inclusion of all society segments into the formal financial system, they made several efforts and adopted different measures. As part of the undertaken efforts, many legal and regulatory reforms were conducted, 
several partnerships were established, and multiple initiatives were introduced.

Despite these efforts, a number of challenges remain and necessitate further efforts. Egypt suffers from high levels of financial exclusion, especially when compared to LMIC and MENA countries groups. Analysis of the access, usage and quality of financial services used by individuals or enterprises clarified that many Egyptians are still excluded from the formal financial system in many aspects. Cost, lack of documentation and distance barriers play considerable roles in this financial exclusion. Women, low-income and young adults are overrepresented among the unbanked. There is greater preference of cash transactions in receiving wages, sending or receiving domestic remittances and saving/ borrowing informally. Mobile money accounts and digital transactions are recording low levels. Possibility of raising emergency funds is faint. Also, firms' access to finance and usage indicators didn't improve significantly over the past years. With a high collateral incidence and high interest rates that lead to a limited access to external funding, they mostly depend on financing investments internally.

To face these challenges, the study recommends actual steps to remove physical, bureaucratic, and financial barriers to expand financial inclusion, and expand electronic banking and mobile money services. Measures to revolutionize post offices can play a leading role. Interest rates and collaterals requirements need to be revised to ameliorate firms access to finance. A bank's collateral regime, ready to accept a growing share of movable assets, is important. Finally, a financial inclusion strategy with specific targets need to be settled and adopted. 


\section{References:}

1. Agyemang-Badu, A., K. Agyei and E. K. Duah, "Financial inclusion, poverty and income inequality: Evidence from Africa", Spiritan International Joumal of Poverty Studies, Vol. 2018 ,(2) 2.

2. Alliance for Financial Inclusion (AFI) "Financial inclusion measurement for regulators: survey design and implementation: policy paper", at:http://www.afi-global.org/sites/default/files/afi_policypaper datameasurement en.pdf

3. Alliance for Financial Irclusion (AFI), Central Bank of Egypt (CBE) and Bridging the Gap, "Integrating gender and women's financial inclusion into national strategies", FIS Working Group Guideline Note, No. 27, April 2019, at: http:INWW.afi-global.org/sites/defaultifilesI publications/04-2019/AFI Egypt20\%gender_AW digital.pdf

4. Alliance for Financial Inclusion (AFI), the Central Bank of Egypt (CBE) and Digital Financial Services (DFS) Working Group, "Financial inclusion through digital financial services and Fintech: The case of Egypf', August 2018, at: http://www.afi-global.org/sites/default/files/ publications/08-2018/AFI Egypt Report AW digital.pdf

5. Al-Waquaa Al-Mariya, "The presidential decree No.141 of 2014 on regulating microfinance activity", Issue No. 46, November 2014 (in Arabic).

6. Al-Waquaa Al-Masriya, "Presidential decree N.89 of 2017 to establish the National Council for Payments", Issue N.5 A, February 13, (in Arabic).

7. Al-Waquaa Al-Masriya, "The law N.18 of 2019 about the regulation of the usage of electronic payment", Issue N.15 (B). April 2019,16 (in Arabic).

8. Anson, J., A. Berthaud, L. Klapper and D. Singer, "Financial Inclusion and the role of post office", Policy Research Working Paper, wps6630, The World Bank, 2013, at: http://documents.worldbank.org/curated/ en/68u321468163464611/pdi/WPS6630.pdf

9. Bank for International Settlements (BIS), "Measures of financial inclusion - a central bank perspective", IFC report, Irving Fisher Committee on Central Bank Statistics, 2016, at: http://www.bis.org/ifcl publlife finan inclu.pdf 
10. Beck, T., A. Demirguc-Kunt and R. Levine, "Finance, Inequality and Poverty: Cross-Country Evidence" NBER Working Paper Series, No. 2004 ,10979, at: http://www.nber.org/papers/w10979

11. Beckzada, M., "Engendering the banking financial institutions in Egypt to enhance financial inclusion", Academia, 2018, at: http:/ www. academia edu/37241907/Engendering the banking financial institutions in Egypt to enhance financial inclusion

12. Central Bank of Egypt (CBE), "Monthly Statistical Bulletin", Different Issues, at: http:INWW.CBE.org.eg

13. Central Bank of Egypt (CBE), "CBE initiatives", (N. d.), at: http //www. cbe.erg.eg/en/Pages/CBElnitiatives. aspX

14. Central Bank of Egypt (CBE), "Circular dated 19 February 2019 regarding banking sector consumer protection", 2019, at: http//www. cbe.org.eg/en/Pages/HighlightsPages/Circular-dated-19-February-2019regarding-Banking-Sector-Consumer-Protection.aspx

15. Center for International Private Enterprise (CIPE), Thebes Consultancy, The Federation of Egyptian Industries and The Federation of Egyptian Banks, "Facilitating bank account transactions: A step towards financial inclusion", 2017, at: http://www.cipe-arabia.org/ files/pdf/Democratic Governance/Banks Accounts for Financial Inclusion English WEB. pdf

16. College of Agricultural Banking Pune (CAB), Access Development Services and Consultative Group to Assist the Poor (CGAP), "Business Correspondents and facilitators: Pathway to financial inclusion?', (N. d.), at: http://inclusivefinanceindia.org/userfile/files/thematic retreats. pdf

17. Cull, R., T. Ehrbeck, and N. Holle, "Financial Inclusion and Development: Recent Impact Evidence", CGAP Focus Note 92, Consultative Group to Assist the Poor, 2014, at: http://www.cgap.org/sites/default/files/ FocusNote-Financial-Inclusion-and-Development-April2014-pdf

18. Dabla-Norris, E., Y. Ji, R. Townsend and D. F. Unsal, "Identifying Constraints to Financial Inclusion and Their Impact on GDP and Inequality: A Structural Framework for Policy", IMF work paper WP/2015 ,22/15, at: http://www.imf.org/external/pubs/ft/wp/2015/ wp1522.pdf 
19. Demirguc-Kunt, A.; L. Klapper, D. Singer and P. V. Oudheusden, "The Global Findex Database 2014: Measuring Financial Inclusion around the World", Policy Research Working Paper 7255, The World Bank, 2014.

20. Demirguc-Kunt, Asli, L. Klapper, D. Singer, S. Ansar and J. Hess, "The Global Findex Database 2017 Report: Measuring Financial Inclusion and the Fintech Resolution", The World Bank, 2018, at: http:// openknowledge.worldbank.org/handle/29510/10986

21. European Bank for Reconstruction and Development, The European Investment Bank, and The World Bank, "What's Holding Back The private sector in MENA: Lessons from the Enterprise Survey", 2016, at: http:/www.enterprisesurveys.org/reports/ /media/GIAWB/ EnterpriseSurveys/Documents/Misc/MENA-Business-Climate2016-. pdf

22. Garcia-Herrero, A. and D. M. Turegano, "Financial inclusion, rather than size, is the key to tackling income inequality", The Singapore Economic Review 2018 ,(1) 63, at: http://www.researchgate.net/ publication/320950989 FINANCIAL INCLUSION RATHER THAN SIZE IS THE KEY TO TACKLING INCOME INEQUALITY

23. Gwalani, H. and S. Parkhi, "Financial inclusion : Building a success model in the Indian context", Procedia Social and Behavioral Sciences, N.378-372, ElSevier, 2014, at: http://www.researchgate.net/ publication/262641575_Financial_Inclusion - Building_a Success Model in the Indian Context

24. Global partnership for financial inclusion (GPFI), "G20 financial inclusion indicators". China, 2016, at: http//www.gpfi org/sites/gpfi! files/documents/ G20\%20Financial $20 \%$ Inclusion $20 \%$ Indicators $20 \%$ $20 \% 282016 \%$ Update $29 \%$.pdf

25. Global partnership for financial inclusion (GPFI), "Financial inclusion action plan", 2017, at: http:/wwww.gpfi.org/sites/gpfi/files/ documents $/ 20 \% 2017 \mathrm{G} 20 \% 20$ Financial $20 \%$ Inclusion $20 \%$ Action $20 \%$ Plan20\%final.pdf

26. Global partnership for financial inclusion (GPFI), "About GPFP", (N. d.), at: http://www.gpfi.org/about-gpfi 
27. Han, R. and M. Melecky, "Financial inclusion for stability: Access to bank deposits and the deposit growth during the global financial crisis", Munich Personal RePEc Archive, MPRA Papers 2013 ,48338, at: http:// mpra.ub.uni-muenchen.de/8/48338/MPRA paper 48338.pdf

28. Hannig, A. and S. Jansen, "Financial inclusion and financial stability: Current policy issues", ADBI Working Paper 2010,259, at: http:// www. adb.org/sites/default/files/publication/156114/adbi-wp259.pdf

29. Honohan, P., "Financial development, growth and poverty: how close are the links?", World Bank Group Working Paper, WPS,3203 2003, at: http:/www. findevgateway,org/sites/default/files/mfg-enpaper-financial-development-growth-and-poverty-how-close-are-thelinks2004-pdf

30. Honohan, P., "Cross-country variation in household access to financial services", presented to the World Bank Conference: "Access to Finance Conference", Washington, 2007, at: http:/www.researchgate. net/publication/222405898 Cross-Country Variation in Household Access to Financial Services

31. Khan, S., "Financial inclusion and financial stability: Are they two sides of the same coin?', BIS central bankers' speeches, November 2011 ,4, at: http://www.bis.org/review/r111229f.pdf

32. Mehrotra, A. and J. Yetman, "Financial inclusion - issues for central banks", BIS Quarterly Review, March 2015, at: http:// papers.ssm.com/ sol3/papers.cfm?abstract id $=2580310$

33. Mohammed, J. I., L. Mensah and A. Gyeke-Dako, "Financial inclusion and Poverty Reduction in Sub-Saharan Africa". The African Finance Journal 2017 ,(1)19, at: http://ideas.repec.org/a/afi/journl/ v19y2017i1p22-1.html

34. Morgan, P. J. and V. Pontines, "Financial stability and financial inclusion", ADBI Working Paper Series 488, Asian Development Bank Institute, 2014, at: http://www.adb.org/sites/default/files/publication/156343/ adbi-wp488.pdf

35. Neaime, S., "financial inclusion, financial stability and inequality", Economic Research Forum (ERF), 2018, at: http://theforum.erf.org. eg/29/01/2018/financial-inclusion-financial-stability-inequality/ 
Park, C., and R. Mercado, "Financial inclusion, poverty, and income inequality in Developing Asia", ADB Economics Working paper series 2015 ,426, at: http://www.researchgate net/publication/274010255 Financial Inclusion Poverty and Income Inequality

37. Sahay, R., M. Cihak, P. N'Diaye, A. Barajas, S. Mitra, A. Kyobe, Y. Mooi and S. Yousefi, "Financial inclusion: Can it meet multiple macroeconomic goals?" , IMF Staff Discussion Note, SDN/2015, 17/15, at: http://www.imf. org/external/pubs/tt/sdn/2015/sdn1517.pdf

38. The World Bank, "Global Financial Development Database (GFDD)", 2017, at: http://www.worldbank.org/en/publication/gfdr/gfdr2016-/data/ global-financial-development-database

39. The World Bank, "The Global Findex Database 2017 ,"2017, at: http:/l globalfindex. worldbank.org/node?field databank country target id =7

40. The World Bank, "The Global financial inclusion and consumer protection survey (FICP)", 2017, at: http:// www. worldbank.org/en/topic/ financialinclusion/briet/ficpsurvey

41. The World Bank, "Enterprise Surveys: Egypt 2016 Country Profile", Enterprise Surveys, 2017, at: http://www.enterprisesurveys.org/ / media/GIAWB/EnterpriseSurveys/_Documents/Profiles/English/ egypt2016-.pdf

42. The World Bank, "Financial Inclusion at a glance", 2018, at: http:// WWW.Worldbank.org

43. The World Bank, "Enterprise surveys: Custom Query", (N.d.), at: http// www.enterprisesurveys.org/Custom-Query\#hReprtpreview

44. Triki, T. and I. Faye, "Financial inclusion in Africa", African Development Bank (AFDB) 2013, at: http /l www.microfinancegateway org/sites! default/files/mfg-en-paper-financial-inclusion-in-africa2013-pdf

45. Yoshino, N. and P. J. Morgan, "Financial inclusion, financial stability and income inequality: Introduction" The Singapore Economic Review 2018 ,(1)63, at: http://www.worldscientific.com/doi/pd//10.1142/ $\$ 0217590818020022$

46. Zulfiqar, K., M. A. Chaudhary and A. Aslam, "Financial inclusion and its implications for inclusive growth in Pakistan", Pakistan Economic and Social Review 2016 ,(2)54, at: http://pu.edu.pk/images/journal/pesrl PDF-FILES/-7V16 2 54.pdf 


\section{مسنتخلص}

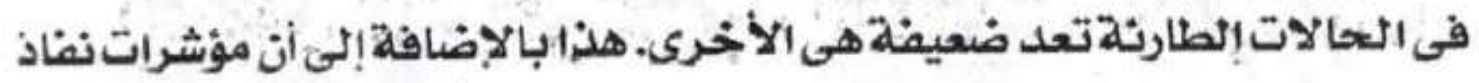

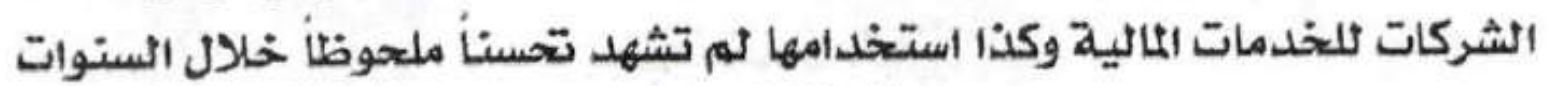
الماضيلة.

ولمواجهة تلك التحديات سالفة الذكر، توصى اللدراسة باتخاذ خطوات جادة

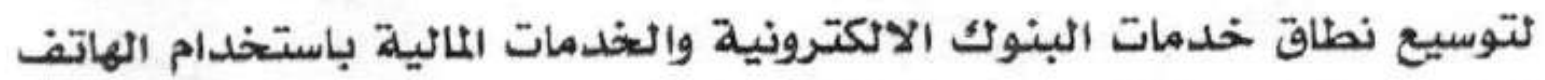

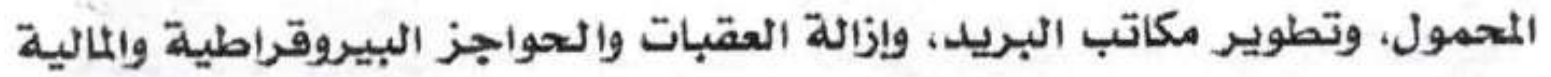

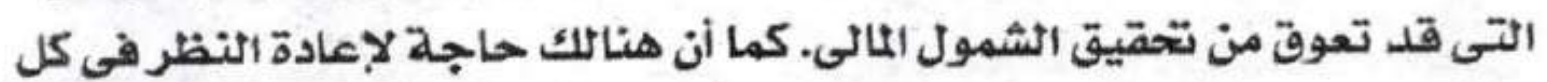

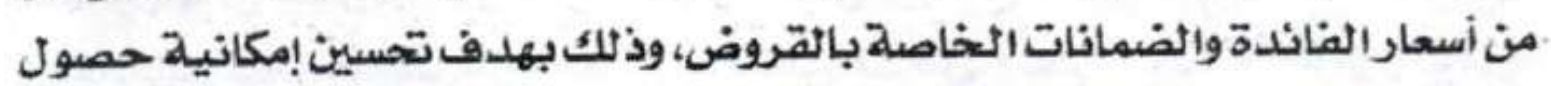

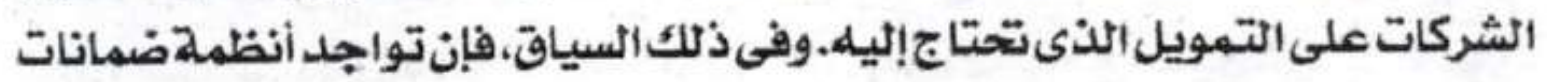

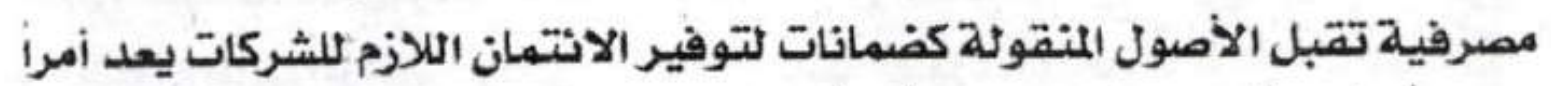

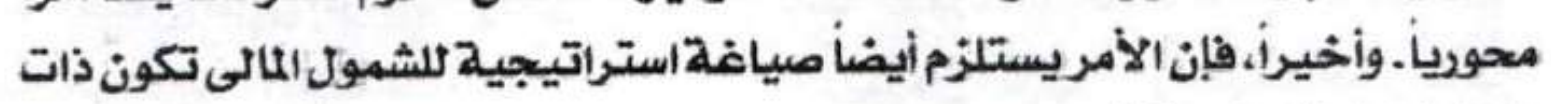
خطط زمنية واضحة وأهداف محددة. الكلمات المثتاحية: الشمول المادلى، مصر، الخخدمات المالية، الاستقرار المالى 


\section{الشهول المالى فى مصر : التحديات والتوصيات

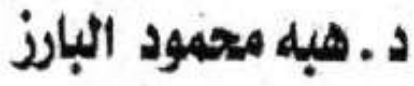

استاذ مساعد الاقتصاد ورئيس قسهم السياسات المالية والنقدية

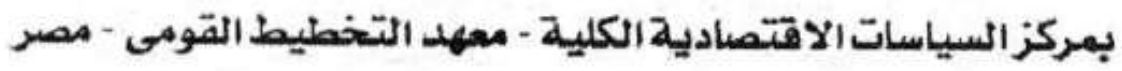

\section{ملنخص:}

يتحظى الشمول الماكى باهتمام متزايد لما لها من آثار إيجابية مالية واقتصعادية.

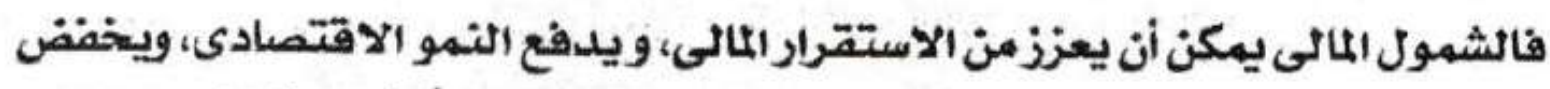

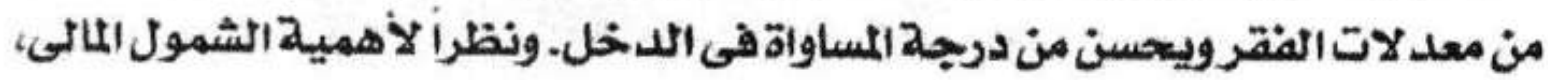

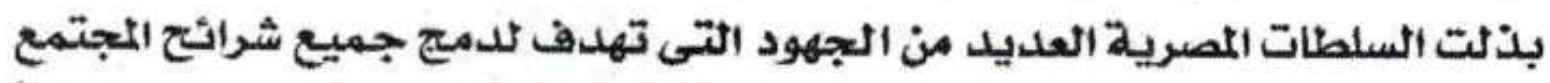

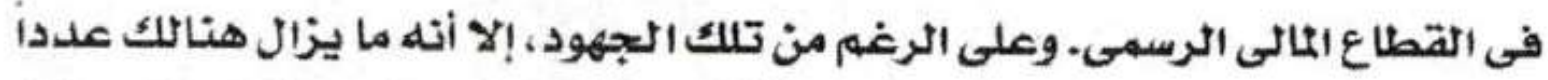

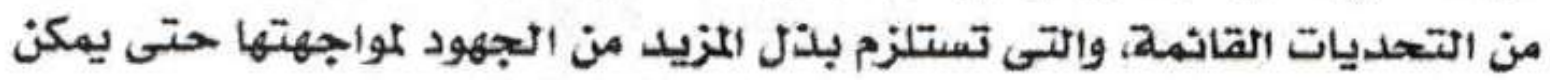

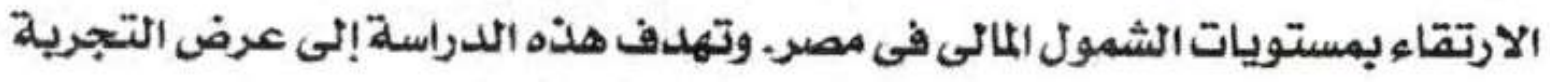

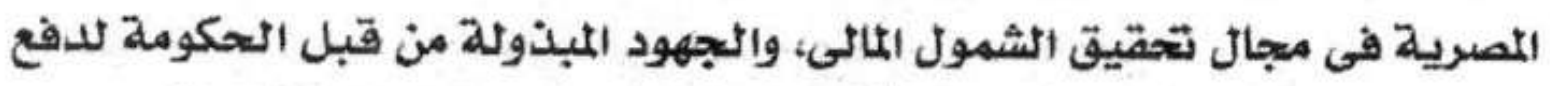
وتعزيز الشمول المالى فى مصر، بالإضافة إلى التحلى فيات التى لا تزال قائمة. وقد توصلت الدراسة إلى أن مصر تعانى من معدلات مرتفعة من الإقصاء المالىى.



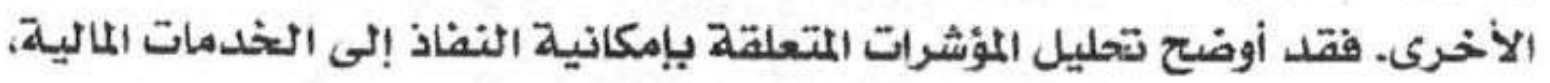

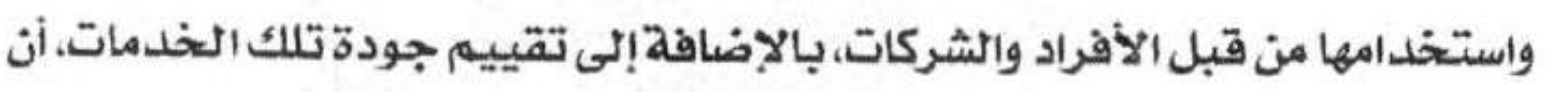

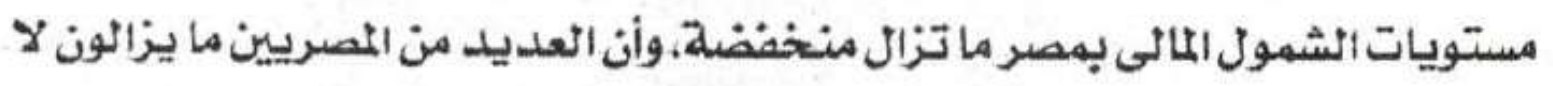

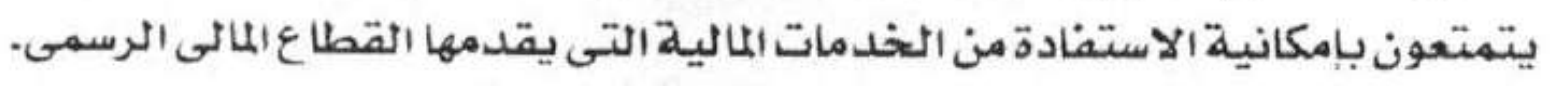

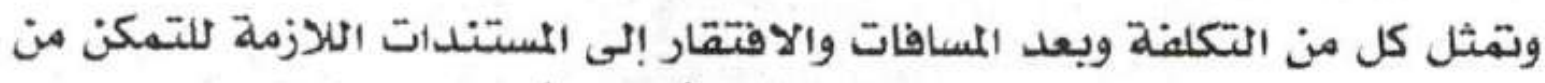

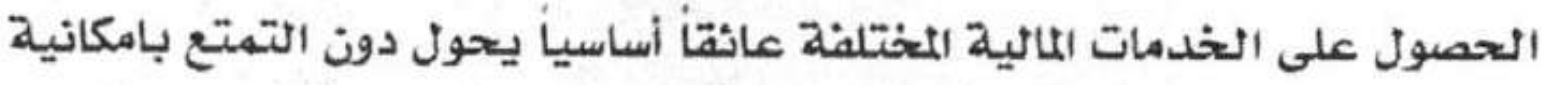

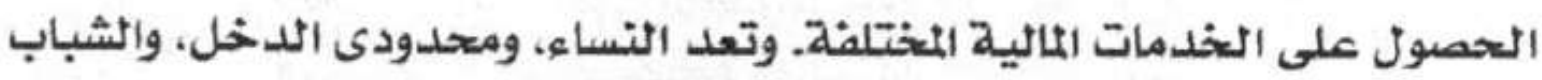

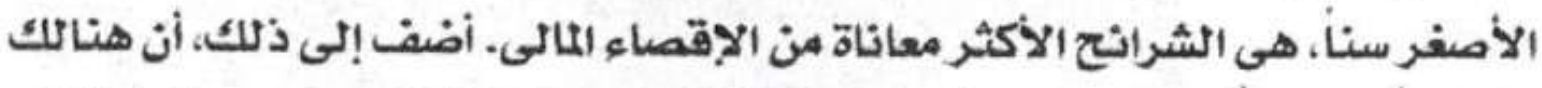

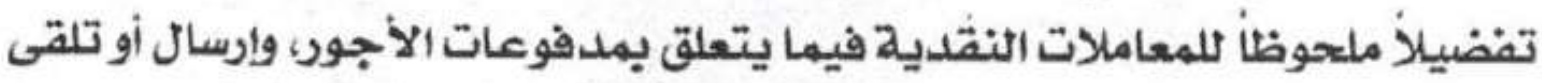

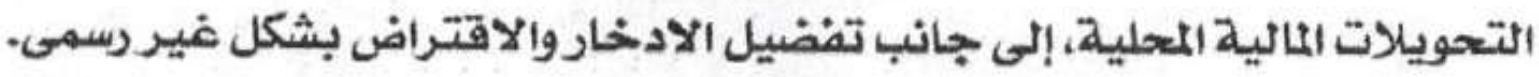

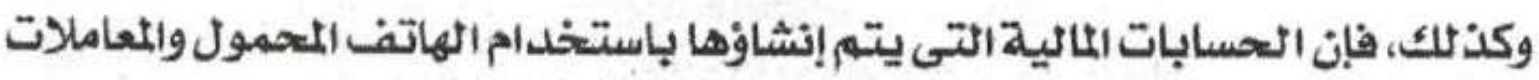
الرقمية تسجل مستويات منتخفضة. كما أن امكانية التحصول على على الأموال 